O OPEN ACCESS phytobiomesjournal.org

\title{
Manipulating Wild and Tamed Phytobiomes: Challenges and Opportunities
}

Terrence H. Bell, ${ }^{1,2,3, \dagger}$ Kevin L. Hockett, ${ }^{1,2,3}$ Ricardo I. Alcalá-Briseño, ${ }^{4,5,6}$ Mary Barbercheck, ${ }^{7,8}$ Gwyn A. Beattie, ${ }^{9}$ Mary Ann Bruns, ${ }^{2,3,10}$ John E. Carlson,, ${ }^{3,10}$ Taejung Chung, ${ }^{3,11}$ Alyssa Collins, ${ }^{1}$ Bryan Emmett, ${ }^{12}$ Paul Esker, ${ }^{1,8}$ Karen A. Garrett, ${ }^{4,5,6}$ Leland Glenna, ${ }^{3,8,13}$ Beth K. Gugino, ${ }^{1}$ María del Mar Jiménez-Gasco, ${ }^{1,8}$ Linda Kinkel, ${ }^{14}$ Jasna Kovac, ${ }^{3,11}$ Kurt P. Kowalski, ${ }^{15}$ Gretchen Kuldau, ${ }^{1,8}$ Johan H. J. Leveau, ${ }^{16}$ Matthew J. Michalska-Smith, ${ }^{14,17}$ Jessica Myrick, ${ }^{18}$ Kari Peter, ${ }^{1}$

Maria Fernanda Vivanco Salazar, ${ }^{8,13}$ Ashley Shade, ${ }^{19,20,21,22}$ Nejc Stopnisek, ${ }^{19,20,21}$

Xiaoqing Tan, ${ }^{3,11}$ Amy T. Welty, ${ }^{9}$ Kyle Wickings, ${ }^{23}$ and Etienne Yergeau ${ }^{24}$

${ }^{1}$ Department of Plant Pathology and Environmental Microbiology, The Pennsylvania State University, University Park, PA, U.S.A.

${ }^{2}$ Intercollege Graduate Degree Program in Ecology, The Pennsylvania State University, University Park, U.S.A.

${ }^{3}$ Microbiome Center, The Huck Institutes of the Life Sciences, The Pennsylvania State University, University Park, PA, U.S.A.

${ }^{4}$ Plant Pathology Department, University of Florida, Gainesville, FL, U.S.A.

${ }^{5}$ Institute for Sustainable Food Systems, University of Florida, Gainesville, FL, U.S.A.

${ }^{6}$ Emerging Pathogens Institute, University of Florida, Gainesville, FL, U.S.A.

${ }^{7}$ Department of Entomology, The Pennsylvania State University, University Park, PA, U.S.A.

${ }^{8}$ International Agriculture and Development Graduate Program, College of Agricultural Sciences, The Pennsylvania State University, University Park, PA, U.S.A.

${ }^{9}$ Department of Plant Pathology and Microbiology, lowa State University, Ames, IA, U.S.A.

${ }^{10}$ Department of Ecosystem Science and Management, The Pennsylvania State University, University Park, U.S.A.

${ }^{11}$ Department of Food Science, The Pennsylvania State University, University Park, PA, U.S.A.

${ }^{12}$ Boyce Thompson Institute, Ithaca, NY, U.S.A.

${ }^{13}$ Agricultural Economics, Sociology, and Education Department, The Pennsylvania State University, University Park, PA, U.S.A.

${ }^{14}$ Department of Plant Pathology, University of Minnesota, St. Paul, MN, U.S.A.

${ }^{15}$ U.S. Geological Survey, Great Lakes Science Center, Ann Arbor, MI, U.S.A.

${ }^{16}$ Department of Plant Pathology, University of California, Davis, CA, U.S.A.

${ }^{17}$ Department of Veterinary Population Medicine, University of Minnesota, Saint Paul, MN, U.S.A.

${ }^{18}$ Bellisario College of Communications, The Pennsylvania State University, University Park, PA, U.S.A.

${ }^{19}$ Department of Microbiology and Molecular Genetics, Michigan State University, East Lansing, MI, U.S.A.

${ }^{20}$ The Plant Resilience Institute, Michigan State University, East Lansing, MI, U.S.A.

${ }^{21}$ The DOE Great Lakes Bioenergy Research Center, Michigan State University, East Lansing, MI, U.S.A.

${ }^{22}$ Department of Plant, Soil and Microbial Sciences; and Program in Ecology, Evolutionary Biology and Behavior, Michigan State University, East Lansing, MI, U.S.A.

${ }^{23}$ Department of Entomology, Cornell University, Cornell AgriTech at the New York State Agricultural Experiment Station, Geneva, NY, U.S.A.

${ }^{24}$ Centre INRS-Institut Armand-Frappier, Institut National de la Recherche Scientifique, Laval, QC, Canada

Accepted for publication 7 March 2019.

${ }^{\dagger}$ Corresponding author: T. H. Bell; thb15@psu.edu

First and second authors co-chaired the symposium and contributed equally to this manuscript.

*The $e$-Xtra logo stands for "electronic extra" and indicates that one supplementary file is published online.

The author(s) declare no conflict of interest.

This article is in the public domain and not copyrightable. It may be freely reprinted with customary crediting of the source. The American Phytopathological Society, 2019. 


\section{ABSTRACT}

This white paper presents a series of perspectives on current and future phytobiome management, discussed at the Wild and Tamed Phytobiomes Symposium in University Park, PA, U.S.A., in June 2018. To enhance plant productivity and health, and to translate lab- and greenhouse-based phytobiome research to field applications, the academic community and end-users need to address a variety of scientific, practical, and social challenges. Prior discussion of phytobiomes has focused heavily on plant-associated bacterial and fungal assemblages, but the phytobiomes concept covers all factors that influence plant function. Here we discuss various management considerations, including abiotic conditions (e.g., soil and nutrient applications), microorganisms (e.g., bacterial and fungal assemblages, bacterial and fungal inoculants, and viruses), macroorganisms (e.g., arthropods and plant genetics), and societal factors (e.g., communication approaches and technology diffusion). An important near-term goal for this field should be to estimate the potential relative contribution of different components of the phytobiome to plant health, as well as the potential and risk of modifying each in the near future.

Keywords: ecology, endophytes, management, microbiome, plant pathology, rhizosphere and phyllosphere.

\section{ABBREVIATIONS AND GLOSSARY}

\section{2,4-DAPG: 2,4-diacetylphloroglucinol}

Biocontrol: the use of living organisms to suppress pests

C: carbon

CBC: conservation biological control; biological control that exploits natural enemies through modification of the environment or management practices

CMD: cassava mosaic disease

Dormancy: period in which an organism's function is slowed, which is reversible under certain conditions

Endophyte: organisms (generally fungi, bacteria, and viruses) that colonize internal plant tissue without causing obvious visible symptoms

HIPV: herbivore-induced plant volatile

Holobiont: host and all of its associated partners

ITS: internal transcribed spacer

Microbiome: All of the microorganisms found in a particular environment. The boundaries on microbiomes are often challenging to define and depend on individual study parameters

$\mathrm{N}$ : nitrogen

P: phosphorous

PapMV: papaya mosaic virus

Phytobiome: all of the biotic and abiotic factors that jointly determine a plant's health and growth

PRSV: papaya ringspot virus

PVX: potato virus $X$

PVY: potato virus $\mathrm{Y}$

SCMV: sugarcane mosaic virus

SynComs: synthetic microbial communities; groups of microorganisms assembled for experimentation by combining multiple isolates

Phytobiomes are not simply the collection of microorganisms associated with a plant, but all of the biotic and abiotic factors that influence the health and productivity of plants in a defined biome. Many living components of the environment shape plant productivity, including other plants, large animals, and various microorganisms, such as viruses, bacteria, fungi, oomycetes, amoebae, and algae. Abiotic factors such as soil and climate also impact plants and regulate the presence and function of the many organisms that interact with them.

Historically, agricultural and natural systems have been managed by focusing on individual components of the phytobiome (e.g., nutrient applications, pesticides, and removal of invasive organisms). However, managing the phytobiome as an integrated system of components has greater potential to achieve optimal and sustainable ecosystem health and productivity. As a step toward advancing phytobiome science and translating lab- and greenhouse-based phytobiome research to the field, approximately 150 people came together for a workshop and symposium entitled Wild and Tamed Phytobiomes on 19 to 22 June 2018. This symposium was the 21st installment of the Penn State Plant Biology Symposium series in University Park, PA, U.S.A. This white paper contains perspectives and findings that were shared among the attendees. A compilation of abstracts from the symposium is provided as Supplementary Material.

Previous perspective papers and reviews have identified key barriers, needs, and opportunities related to plant-associated microbiome 
research (Busby et al. 2017; Farrar et al. 2014; Hawkes and Connor 2017; Lebeis et al. 2012; Mueller and Sachs 2015), and another has presented an overarching vision for integrated phytobiome research (American Phytopathological Society 2015; www.phytobiomes.org/ Roadmap/Documents/PhytobiomesRoadmap.pdf). Here, we present insights from discussions on the opportunities and challenges related to understanding and manipulating the wide array of factors that influence the function of both wild and tamed plant systems, as well as considerations on communicating this science to stakeholders and the broader public.

\section{PERSPECTIVES ON MANAGING AND MANIPULATING PLANT-ASSOCIATED MICROBIOMES}

\section{How might soil properties constrain phytobiome manipulation?}

\section{Contributed by Mary Ann Bruns}

Wild and tamed phytobiomes correspond to plants growing in undisturbed and domesticated soils, respectively (Amundson et al. 2015). Tamed systems offer the greatest potential for effective manipulation. Generally speaking, inherent soil properties (e.g., climate, depth to bedrock, slope, and texture) are geospatially determined, making them difficult or impossible to change, and imposing a priori constraints on which phytobiomes can be established. Alterable soil properties (e.g., organic matter content, $\mathrm{pH}$, porosity, biological activity, and macronutrients) are strongly shaped by biotic factors, being modified by vegetation, microbial activity, and human management. For phytobiomes, resource availability is the most important category of properties influencing the strength and direction of plant-soil feedbacks. Under low nutrient availability, plants allocate less photosynthate to roots than they do under high nutrient availability, leading to lower overall soil microbial biomass (Treseder 2008) and weaker interactions between roots and microbial biotrophs (Johnson et al. 2010). Soil microbial succession, adaptation, and $\mathrm{C}$ cycling are also affected by resource availability, thereby resulting in persisting legacy effects (Kaminsky et al. 2018; Martiny et al. 2017; Treseder et al. 2011). Revillini et al. (2016) showed that plant biomass was higher in sterile soils inoculated with microbial communities from a nonfertilized soil than with communities from a fertilized soil. Thus, the success or failure of phytobiome manipulation may depend on compatible adjustments of resource availability through soil management.

Soil properties are dynamic and will affect functional (saprotrophs, biotrophs, and specialists) and morphological microbial groups in different ways (Delgado-Baquerizo et al. 2016; Tedersoo et al. 2014). Microbial activity itself results in changes in soil structure through aggregate formation and stabilization (Six et al. 2004), macropore creation, and altered hydraulic conductivity, all of which have contrasting effects on growth and dispersal of filamentous and nonfilamentous microbes (Wolf et al. 2013). Interdependencies among alterable properties, such as $\mathrm{pH}$, redox potential, and nutrient chemical speciation, also result in direct and indirect impacts on microbial habitats. Soil $\mathrm{pH}$, for example, is a highly influential but spatially variable factor affecting bacterial diversity (Lauber et al. 2009). In the rhizosphere, $\mathrm{pH}$ can be determined by the predominant $\mathrm{N}$ species taken up by plant roots $\left(\mathrm{NH}_{4}{ }^{+}\right.$or $\left.\mathrm{NO}_{3}{ }^{-}\right)$, so that source and type of fertilizer $\mathrm{N}$ could influence diversity of rhizosphere microbes. Because root sensing and signaling are also affected by rhizosphere pH (Xuan et al. 2017), fertilizer type would influence the ability of roots to attract compatible microbial partners. While inherent soil properties determine land use suitability and vegetation type, alterable properties can be fine-tuned to shape soil-phytobiome feedbacks, particularly in agricultural soils and engineered growth media.

\section{Managing agricultural soils to enhance the phytobiome}

\section{Contributed by Bryan Emmett}

Phytobiome-based management presents an opportunity to support plant productivity, while limiting saturating external nutrient inputs. The last two decades of research have increasingly highlighted mechanisms of microbial facilitation of plant nutrient use. Nutrients that are not readily mineralized in the absence of the plant can be available to plant-microbe interactions, including widespread priming effects on $\mathrm{C}$ and $\mathrm{N}$ mineralization and solubilization of phosphate in the rhizosphere (Cheng et al. 2014; Zhang et al. 2016; Zhu et al. 2014a). Certain nutrient fluxes are driven largely by well-known mutualisms (e.g., $\mathrm{N}_{2}$ fixation). However, others are mediated by the broader microbial community and optimizing this phytobiome-mediated nutrient supply necessitates a systems-based approach that accounts for the soil habitat and nutrient pools available throughout the phytobiome, rather than focusing solely on known beneficial taxa.

Recent research highlights the interdependency of phytobiome components that are responsive to management. For example, overwintering cover crops and diversified rotations are effective tools to increase soil $\mathrm{C}, \mathrm{N}$, and microbial biomass in soils (McDaniel et al. 2014). In turn, these parameters are key drivers of soil- and plant-associated microbiome composition (Berthrong et al. 2013; Hamel et al. 2018). Moreover, Berthrong et al. (2013) found that management-induced increases in soil $\mathrm{C}$ and $\mathrm{N}$ stocks and associated shifts in soil microbial community composition led to increased $\mathrm{N}$ mineralization following labile $\mathrm{C}$ addition, potentially linking rhizosphere effects and improved plant $\mathrm{N}$ supply under diversified rotations.

The challenge of the next decades will be to move from experimental examples to a robust understanding of the management levers influencing agricultural phytobiomes and a prescriptive knowledge of the rotations, crop selection, residue management, and tillage practices that optimize phytobiome function. The inherent variability of diverse soils and sites presents a challenge to this effort. A network of researchers collecting data and assessing management interventions across sites will be essential to address this challenge. Working farms have always been an incubator for agricultural innovation and experimentation. Data generation and processing capabilities are now scaling to a point where it is possible to envision harnessing this experimentation at a scale that can unravel the complexity present across sites and soils, and identify microbial taxa, networks, and functions that are responsive to management.

\section{Delving into the plant-microbiome-environment nexus with a focus on drought}

\section{Contributed by Gwyn Beattie and Amy Welty}

Due to their sessile state, plants are inherently vulnerable to the vagaries of weather and soil conditions. The mobility of microbes coupled with their potential to form intimate associations with plants enables microbial-induced phenotypic plasticity that modulates plant responses to stress. Knowledge of the contributions of individual microbes to plant stress tolerance has been increasing, particularly with respect to drought (Dimkpa et al. 2009; Kasim et al. 2013; Latef et al. 2016; Ngumbi and Kloepper 2016; Rho et al. 2018; Rolli et al. 2015). Given the huge global diversity of plant species and of dynamic plant habitats, the beneficial plant-microbe interactions that are currently characterized represent only a fraction of the 
interactions that bolster plant fitness. In-depth knowledge of the plant-microbiome-environment nexus is key to managing crop phytobiomes, and to harnessing beneficial associations in the face of challenges such as climate change, water scarcity, and degraded soils.

Many approaches can lead to the discovery of microbes and microbial community traits that enhance crop performance under nonideal conditions. Historically, cultivated isolates have been screened for beneficial impacts, and some have been developed into agricultural products, such as those that enhance drought tolerance. Recent studies characterizing the soil microbiome as a whole have demonstrated that, during the growth of plants under drought stress, changes occur in soil microbial assemblages that favor plant fitness in subsequent generations if those plants are also grown under drought conditions (Lau and Lennon 2012). Beattie and colleagues have investigated the nature of these microbial assemblage changes by profiling communities during multigenerational growth of soybeans in low and high soil moisture conditions. They discovered a notable enrichment in members of the phylum Actinobacteria in roots under drought stress (unpublished data). These findings echo those of two recent studies (Fitzpatrick et al. 2018; Xu et al. 2018), which also documented drought-associated increases in rootassociated Actinobacteria in diverse plant species.

The complexity of a phytobiome can be daunting when searching for the functional interactions among the many involved players. Although the functional relevance of interactions at the cropActinobacteria-drought nexus have not yet been demonstrated, the identification of consistent associations among these players is a critical step toward both understanding phytobiomes and using this information to improve crop health and productivity under drought conditions. Given the increasing challenge that drought poses to global crop productivity (Daryanto et al. 2017; Lesk et al. 2016), strategies that exploit all components of phytobiomes are needed to maximize the resilience of our agroecosystems.

\section{Assembly and activation of the rhizosphere microbiome during plant stress}

\section{Contributed by Ashley Shade and Nejc Stopnisek}

Interactions between bacteria and plants in the rhizosphere are important for plant wellness and productivity (Berendsen et al. 2012; Coleman-Derr and Tringe 2014; Pieterse et al. 2014). Assembly and maintenance of rhizosphere bacterial assemblages are primarily driven by root exudates that add $\mathrm{C}$ and nutrients to the soil system (Hu et al. 2018; Zhalnina et al. 2018). However, changes in root exudates can occur when plants experience biotic or abiotic stress, which can in turn alter the composition or activities of the rhizosphere microbiota (Lebeis et al. 2015; Sasse et al. 2018). Rhizosphere soils are a resource-rich hotspot of microbial activity (Ma et al. 2018). However, soils harbor a sizeable diversity reservoir, including numerous rare and inactive (dormant) taxa (Lennon and Jones 2011). Dormant microbial taxa can resuscitate, and rare taxa can bloom to provide pulses of activity under specific environmental conditions (Shade and Gilbert 2015). The roles of diversity reservoirs in the assembly and dynamics of the rhizosphere community microbiomes are unknown, as are the changes in microbial activities in response to changes in root exudates during stress.

To improve understanding of the phytobiome, there is a need to consider the dynamics of microbial dormancy, resuscitation, and changes in relative activities in the rhizosphere during plant stress. An integrated approach that considers both the microbiology and chemistry of the phytobiome is likely to be particularly fruitful. First, a baseline of precise chemistry of root exudates in "good" times of plant wellness is required. This information should include the resolved spatial dynamics of root exudates, given root architecture and its micron-scale heterogeneity, as well as the resolved temporal dynamics over development of the growing season for both perennial and annual plant life history strategies. This information can then be compared with changes in exudates during stresses like drought, increased temperature, resource excess and limitation, herbivory, and pathogen infection. Finally, quantitative measurements of microbial activity and dormancy are required to develop an understanding of the dynamics of microbial diversity reservoirs, including dormant and rare taxa (Bowsher et al. 2018). The conditions of dormancy and rarity are temporary, and reactivation of these microbiome constituents can fundamentally change the functional profile of the rhizosphere. Development of high-throughput, quantitative methods for measuring microbial activity in situ will allow for precise tracking of key microbiome functions over time and in response to stress. Likewise, expanded infrastructure and standard analysis workflows for high-throughput metabolite analysis will be key for supporting comparisons across studies and plants.

\section{Manipulating the crop holobiont for increased stress resistance}

\section{Contributed by Etienne Yergeau}

It is estimated that by 2050 , drought episodes will impact $>50 \%$ of the world's arable land, causing serious yield losses in major crops (Ngumbi and Kloepper 2016). An interesting framework for studying the adaptation of host-associated microorganisms to stressful events is the hologenome theory of evolution. This theory postulates that the complex interacting network, involving a eukaryotic host and all of its associated microorganisms and other partners (the holobiont), acts as a unit of evolution (Zilber-Rosenberg and Rosenberg 2008). As such, rapid adaptations of holobionts are thought to be more likely related to changes in plant-partnered organisms, through mechanisms such as recruitment, amplification/reduction, and horizontal gene transfer, suggesting a clear path to the improvement of plant resistance and resilience to stress (Berendsen et al. 2012; Duhamel and Vandenkoornhuyse 2013; Nogales et al. 2016; Rosenberg and Zilber-Rosenberg 2016). Most efforts to date have focused on trying to direct microbial recruitment by the plant by providing selected microbial strains or assemblages. For instance, the priming of seeds with single microorganisms has often been used to supplement the rhizosphere microbiome (Parnell et al. 2016). However, this technique can sometimes be of limited success, mainly because it underestimates the importance of the biotic context (microbe-microbe and plantmicrobe interactions) for optimized colonization (Rivett et al. 2018). Complex communities that target multiple niche spaces and exhibit functional redundancy might be better at entering and surviving a new environment than single species (Yergeau et al. 2015).

Knowledge of how microbiomes coalesce is still minimal (Rillig et al. 2015), but we know that established soil inhabitants can prevent the success of newcomers, a phenomenon referred to as priority effects (Vannette and Fukami 2014). Priority effects might be overcome when established microbial assemblages are weakened by environmental stressors (Calderón et al. 2016), such as drought. Such processes are potentially more complex under the influence of a plant, which can partly determine which microorganisms stay, and which do not (Mueller and Sachs 2015). Translating this theoretical framework into applied solutions for rapidly adapting crops to abiotic stresses remains an unmet challenge.

\section{Storage and reproduction of microbiomes}

\section{Contributed by Terrence Bell}

Controlled systems, such as incubators, growth chambers, and greenhouses, are key tools for parsing the factors that shape soil and 
plant-associated microbiome structure and function. Although conditions such as temperature, moisture, and plant variety are easy to control, it is challenging to standardize the microorganisms that we work with. This complicates the comparison of studies run by different research groups and at different points in time. When searching the methods section of such studies, it is common to find that the soil and associated microorganisms came from a nearby experimental station, or an investigator's backyard. This contrasts with descriptions of biological material used in cell culture, which are more in line with the following: "MDA-MB-231 cells were obtained from the American Type Culture Collection" (Li et al. 2017).

Synthetic microbial communities (SynComs), i.e., mixtures of cultivated bacterial isolates, have been applied to address this issue in some studies (Castrillo et al. 2017; Lebeis et al. 2015). SynComs allow for the removal or replacement of specific isolates, to investigate the impacts of each isolate individually. Some disadvantages of this approach, as currently applied, are that (i) yet-to-be-cultivated microbial lineages are excluded, and (ii) a group of unconditioned isolates will lack many of the interactions that would be selected for over time in a true assemblage. Several studies show that microbial phenotypes can differ dramatically after multiple generations of selection in isolation, as opposed to the same amount of selection within a multistrain assemblage (Fiegna et al. 2015; Ketola et al. 2016; Lawrence et al. 2012). This latter issue could be resolved through differential conditioning of SynComs, followed by preservation at specified generations.

However, the former issue suggests that there is value in cultivation-independent approaches to microbiome preservation and transfer. In addition to retaining yet-to-be-cultivated microbes, preserving microbiomes directly from soils without cultivation would facilitate screening for desirable group phenotypes (e.g., low carbon dioxide output and high $\mathrm{N}$ retention) across many soil types and locations. Although it may be challenging or impossible to directly reproduce microbiomes found in the field, the generation of replicable storage and experimental conditions should allow for reasonable reproduction of lab-adapted microbiomes across generations (Auchtung et al. 2015). Williams and Marco (2014) showed that cryopreservation only minimally impacted the microbiome transferred from field-grown lettuce to lettuce grown in the lab, indicating the potential to maintain stored microbiome collections. Beyond simply preserving microbiomes, it is important to consider the impacts of different microbiome transfer approaches, which can also have large impacts on microbiome composition in study systems (Howard et al. 2017).

Moving forward, we should consider how best to preserve and distribute both intact microbiomes and diverse SynComs for replicated experimental design through space and time. Given that barcode identifications are not sufficient for predicting all microbial functions and traits, these resources should be preserved with metadata that provides insight into the observed function of the assemblages at the time of preservation.

\section{Shaping microbiomes with microbial warfare}

\section{Contributed by Kevin Hockett}

Plant-associated microbes have long been known to produce chemicals and proteins that are antagonistic toward potentially cocolonizing microbes. These include secondary metabolites (e.g., antibiotics, Haas and Defago 2005), contact-dependent mechanisms (type V and type VI secretion systems, Hayes et al. 2014), protein toxins (bacteriocins, Ghequire and De Mot 2014), and other protein exoenzymes. Although substantial research has demonstrated the activity of antagonistic systems in culture environments and has allowed prediction of the genetics underlying such systems in genomic and metagenomic studies of plant-associated microbes, our understanding of how most antagonistic traits influence plantassociated microbial assemblages under natural conditions remains limited.

One of the best understood examples of antagonism under field settings is the suppression of take-all (a soilborne root disease caused by Gaeumannomyces graminis var. tritici) of wheat by fluorescent Pseudomonas spp. in disease-suppressive soils. This antagonism is linked to a suite of secondary metabolites produced by these organisms, chief among them being 2,4-diacetylphloroglucinol (2,4-DAPG) (Haas and Defago 2005). Although the role and activity of 2,4-DAPG producing Pseudomonas spp. in suppressing soilborne fungal diseases has been elucidated through decades of research conducted by several laboratories, such detailed understanding of antagonism in most other systems is lacking. One reason the causal link between 2,4-DAPG production and inhibition of take-all has been so strong is that the discovery of 2,4-DAPG producers stemmed from an initial observation of take-all decline, where the severity of take-all decreases over successive seasons of continuous wheat monocropping (Kwak and Weller 2013). This is in contrast to the majority of instances, in which plant-associated isolates are screened for antagonistic activity in culture first, and then assayed for pathogen inhibition within a plant environment.

While most research on antagonism has focused on taking advantage of these systems for the purposeful exclusion of a pathogen, more research should be directed toward understanding the role of microbial warfare under natural conditions. Chief among the questions that should be asked is: under what conditions does a given form of antagonism contribute to ecological fitness for the producing organism? Antagonistic traits are costly, and thus are almost certainly regulated in a manner that provides the greatest net benefit to the producer. Future research should be aimed at understanding the specific environmental and ecological context(s) in which a given antibiotic or bacteriocin provides such a benefit and when such contexts(s) arise in agricultural or other managed settings. Recent work by Dorosky et al. (2018) demonstrated that loss of production of either of two distinct bacteriocins resulted in reduced persistence within a wheat rhizosphere environment. Conversely, neither bacteriocin affected persistence in bulk soil or in a rhizosphere environment that lacked microbial competitors. Similar work investigating competition between two Xanthomonas tomato pathogens indicated that bacteriocin-mediated inhibition was more prominent on the leaf surface than leaf apoplast (Hert et al. 2009). This may be a contrived example, however, as the bacteriocin-producing strain was engineered to be compromised in pathogenicity.

Regardless, a better understanding of the natural role of microbial warfare will result in a better sense of how best to take advantage of these systems for phytobiome benefit. For instance, rather than attempting to use these systems for excluding a given pathogen, they may provide more reliable benefit in ensuring competitive colonization by beneficial organisms, or potentially in promoting greater diversity within the microbial fraction of the phytobiome, which itself may result in plant benefit in a number of different ways. Broadening our perspective on the utility of microbial antagonism beyond pathogen suppression will likely provide useful strategies for phytobiome management.

\section{Wild, tamed, then back to where the wild things are: discovery and use of biocontrol agents}

\section{Contributed by Johan Leveau}

Plant pathologists tend to classify individual plant-associated microorganisms as either capable of causing disease or not capable 
of causing disease. The traditional path to pathogen discovery involves culture-dependent isolation of candidate microorganisms, based on consistent association with disease symptoms, characterization in the laboratory, and inoculation of plants in the greenhouse or field, with the intent of reproducing symptoms and confirming pathogenicity. Complications may arise when a pathogen is not culturable (e.g., plant viruses or bacteria with Candidatus status) or when a disease is "complex," i.e., caused by a combination of two or more pathogenic microorganisms. In such cases, a culture-independent, DNA-based approach may offer further insight. Typically, this involves high-throughput sequencing of whole plant-associated microbiomes, also known as metagenomics (Leveau 2007), or with a specific focus on taxonomically informative gene amplicons, such as 16S rRNA genes for bacteria, or the internal transcribed spacer (ITS) region for fungi (Rastogi et al. 2013). The success of this approach depends on many factors, but it is critical to compare and contrast microbial profiles from diseased and healthy plant material, to identify candidate pathogenic taxa as those that are only, or more abundantly, associated with diseased plants.

Biological control of plant diseases is a cultural practice that aims to lower the impact of plant pathogens through the use of microbial agents. The typical pipeline for discovery of biocontrol agents is very similar to that described above for pathogens. It typically involves the culture-dependent isolation of "wild" microbes from plants, soils, or other environments, screening them for antagonistic activity in the lab, and taking these "tamed" candidates to the greenhouse or field ("where the wild things are"), in the hopes that they reduce symptom formation on pathogenchallenged plants. As with pathogens, there are likely to be microorganisms with biocontrol potential that are not readily culturable. In addition, there are probably plant-protective effects that are a function of the interaction between two or more microbial taxa (i.e., complex biocontrol) (Xu et al. 2011). Such microorganisms may be of limited practical interest, as their resistance to culture, or dependence on other microorganisms, may pose considerable challenges for commercial exploitation. As with pathogens, the choice of source material for discovering biocontrol agents may be guided by the principle of consistent association. A classic example is the phenomenon of disease-suppressive soils (Schlatter et al. 2017), from which biocontrol agents have been successfully identified through both culture-dependent and -independent means.

DNA-based interrogation of plant-associated microbiomes may one day become the basis for decision-making tools that help farmers/growers manage their fields and maintain healthy and productive crops. To be most effective, such tools should detect not only pathogens, but also microorganisms with pathogen-suppressive potential. Based on profiling of complete plant-associated microbiomes, a farmer may calculate a pathogen/antagonist ratio for their field (analogous to a pest/defender or prey/predator ratio as used in integrated pest management, see Naranjo and Ellsworth 2009) and choose to rely on the native microbiota to keep a pathogen in check, or opt for intervention by specific stimulation of pathogensuppressive taxa. If such taxa are absent, this could occur through the introduction of biocontrol agents that are specifically tailored to target the pathogen, and specifically fit for "where the wild things are." Progress toward this form of microbiota-informed disease management requires many more field observations of natural and experimentally imposed conditions of consistent association, to establish cause and effect of pathogen and nonpathogen co-occurrence. In other words, to tame your plant-associated microorganisms is to know your plant-associated microorganisms.

\section{Can we manage endophyte functionalities?}

\section{Contributed by María del Mar Jiménez-Gasco and Gretchen Kuldau}

Endophytes are organisms (generally fungi, bacteria, and viruses) that colonize internal plant tissue without causing obvious visible symptoms (Petrini 1991; Wilson 1995). Although we focus here on fungal endophytes, these concepts apply to other microorganisms. There is little evidence that we can easily manage endophyte functionalities. The best known, studied, and commercialized example of endophyte management is that of temperate grass endophytes in the genus Epichlö̈ (Schardl et al. 2004; Tanaka et al. 2012). These naturally occurring endophytic fungi are demonstrated to confer benefits to their host, such as drought tolerance and antiherbivory, mediated by the production of an array of secondary metabolites (Kuldau and Bacon 2008). The protective characters of species in this genus resulted in commercialization of grass seed containing the fungus, which is vertically transmitted through seed for forage and turf applications (Johnson et al. 2013a). Adoption of endophyte-infected tall fescue in the southeastern United States is high, since this forage crop is able to withstand high summer temperatures (Bacon 1995). However, cattle grazing on this crop often have compromised health and productivity, due to the presence of ergot alkaloids produced by the endophyte (Beck et al. 2008). Identification of a naturally occurring isolate that does not produce the ergot alkaloids led to development of seed colonized by a "friendly endophyte," which still confers drought tolerance, without negatively impacting cattle health (Beck et al. 2008). This example of manipulating endophyte function is based on decades of research by numerous researchers. However, such manipulation is typically limited by substantial knowledge gaps.

A major gap is our lack of understanding of the ecological roles of fungal endophytes, despite the ubiquity and abundance of this functional guild. Epichlö endophytes, described above, are specialized, obligate, highly coevolved beneficial mutualists (Schardl et al. 2004). This sort of relationship likely represents a very small fraction of all endophyte-host relationships. A growing body of work suggests that the leaf endophytes of deciduous woody perennials might act as saprotrophs in decaying leaf litter, and that the endophytic habit is a transient life stage (Guerreiro et al. 2018). Similarly, root-inhabiting dark septate endophytes may be acting as saprophytes, given their demonstrated capabilities in the degradation of detritus (Caldwell et al. 2000).

One of the main questions that needs to be addressed is the extent to which we can assign functionality to identified endophytes. Most fungal endophytes are generalists, not obligate symbionts (Rodriguez et al. 2009). Rodriguez et al. (2009) put forth a classification of endophyte types, based largely on location of growth within host plants. This work also highlighted the ubiquitous nature of fungal endophytes: class 1, Clavicipitaceous (including Epichlö̈); class 2, non-Clavicipitaceous fungi colonizing the entire plant; class 3, non-Clavicipitaceous hyperdiverse fungi colonizing aerial plant tissues; and class 4 , dark septate endophytes. One example is Fusarium oxysporum, a species generally recognized as a plant pathogen. However, saprophytic and endophytic lifestyles are more common for F. oxysporum than plant pathogenicity (Demers et al. 2015; Stergiopoulos and Gordon 2014), and may be the result of a continuum of interactions with the plant. Another example of wellknown plant pathogens with endophytic biology is Verticillium dahliae. The same genotype of $V$. dahliae may be pathogenic to one host, but act as a nonharmful endophyte in another. In 
addition, changes between endophytic and pathogenic interactions may depend on factors such as host plant genotype or environmental conditions (Malcolm et al. 2013).

Interest in microbial endophytes stems in part from their potential for beneficial interactions with their hosts. Generally fungal endophytes are known for production of bioactive secondary metabolites and have been studied extensively in search of compounds with pharmaceutical value. But fungal endophytes have also been attributed numerous other beneficial traits, mostly through unknown mechanisms. Fungal endophytes can confer plant growth promotion mediated by phytohormones (Ali et al. 2017). Pest and pathogen resistance/deterrence and biocontrol activity have been associated with plant colonization by fungal endophytes, through induction of resistance mechanisms in the plant such as systemic acquired resistance, among others (Quesada-Moraga et al. 2014). Resistance/tolerance to environmental stress has been well documented for the endophyte $F$. culmorum, conferring salt tolerance to salt-sensitive plants (Rodriguez et al. 2008; Sikora et al. 2008). Finally, nonmycorrhizal root endophytes (dark septate endophytes) have been shown to improve $\mathrm{P}$ solubilization and plant uptake (Newsham 2011). Plant growth promotion through P mineralization and solubilization, as well as uptake, may be increased by the synergistic relationship between arbuscular mycorrhizal and dark septate endophytes (Della Monica et al. 2015).

The ecological role of fungal endophytes and the secondary metabolites they produce is mostly unknown. However, the role of several Epichloë endophyte metabolites such as peramine and loline in insect deterrence is elucidated (Johnson et al. 2013a). Understanding metabolite roles in the ecology and biology of their producers, and their interactions with host plants, is needed to advance a more complete picture of these fungi in the larger phytobiome context. The importance of understanding this complexity is illustrated by microbial coculturing studies, which indicate that the presence of other microbes can both elevate levels of secondary metabolite production, and in some cases, induce the production of secondary metabolites not previously known to be produced by the organism under study (Abdalla et al. 2017). Similarly, the host plant, and specific plant environment, can influence expression of secondary metabolites by endophytes (Schmid et al. 2017).

\section{Virome management}

\section{Contributed by Ricardo I. Alcalá-Briseño and Karen Garrett}

Virome management is an important frontier for phytobiome research. Viruses are particularly abundant and diverse organisms (Rodrigues et al. 2017; Suttle 2005). In the plant virome, spatial structuring of viruses is generally based on the compartmentalization of the cell: typically RNA viruses replicate in the cytoplasm, associated with membranes or replication complexes, and DNA viruses replicate in the nuclei. This spatial structuring may prove to have an important role in virus-virus interactions, analogous to larger-scale spatial structuring of bacteria or fungi growing in soil, on plant surfaces, or as endophytes.

Viruses and their interactions result in a range of plant symptoms, from necrosis, to foliar deformation, to common mosaic symptoms, and even to a persistent asymptomatic state (King et al. 2011; Roossinck et al. 2011). Strains of potato virus Y (PVY) cause a range of symptoms on potato, from mild to necrotic strains (Cuevas et al. 2012). However, interactions with other viruses, such as potato virus $\mathrm{X}(\mathrm{PVX})$ can cause an increase or decrease in the severity of the disease. This type of interaction has also recently been described in papaya, with the interaction of papaya ringspot virus (PRSV), a potyvirus, and papaya mosaic virus (PapMV), a potexvirus
(Chavez-Calvillo et al. 2016; Vance 1991). Severe diseases can be caused by interacting viruses, such as maize lethal necrosis caused by the interaction of maize chlorotic mottle virus, a tombusvirus, and at least one of four species of potyvirus within the sugarcane mosaic virus (SCMV) group (Adams et al. 2005, 2013). Another example of multiple interactions causing a devastating agricultural problem is cassava mosaic disease (CMD), where up to seven begomovirus species, and recombinants, are the cause of a pandemic in East and Central Africa (Legg et al. 2015). A sharp increase in the abundance of the whitefly vector was associated with the spread of CMD (Legg et al. 2011, 2015). In the case of PVY, high aphid species richness may slow spread of the pathogen (Claflin et al. 2017). Warmer temperatures often result in larger populations of aphids, one of the main vectors of plant viruses, while temperatures around $30^{\circ} \mathrm{C}$ have been reported to increase virus fitness in plants. Climate change impacts host-pathogen dynamics and host-pathogen-vector interactions, and these changes could impact crop yields (Boyko et al. 2000; Canto et al. 2009; Durak et al. 2016; Kido et al. 2008; Roos et al. 2011).

As plant viromes are more commonly studied, many new types of virus interactions will likely be revealed, and understanding these interactions may be useful for anticipating disease emergence. Complex viromes, including both RNA and DNA viruses, as well as phytobiomes more generally, can be analyzed using bipartite networks. In this context, the direct links in bipartite networks may represent associations between virus species nodes and "sample type" nodes-where sample types might represent host species, vector species, or environmental types. These sample types may be linked indirectly to each other through shared viruses (as discussed in Garrett et al. 2018). With the use of high-throughput sequencing technologies, asymptomatic infections have increasingly been reported in crops and wild plants (Roossinck 2015). Coinfections of plant viruses are now being studied that would likely have been overlooked by more specific serological or molecular techniques (Massart et al. 2014). As plant viromes are more commonly studied, many new types of virus interactions will likely be revealed, and understanding these interactions may be useful for anticipating disease emergence and for identifying antagonistic interactions that can be used to manage viruses.

More complete analyses of viromes will include persistent plant viruses whose role remains unknown, and environmental viruses such as genomoviruses identified in many types of environments, including plants. Understanding the interactions within the phytovirome will contribute to a fuller understanding of the phytobiome, with the potential to inform novel strategies for predicting disease emergence, and for improving integrated plant health management more generally.

\section{Dissecting the phytobiome: network analyses as a tool for linking biological organization to organismal and holobiont phenotypes}

\section{Contributed by Linda Kinkel and Matthew J. Michalska-Smith}

Despite the widespread recognition of the phytobiome as an important ecological unit of organization, we remain limited in our understanding of the ways in which phytobiome phenotype (hereafter, "phenotype"; e.g., yield, health, productivity, and stress resilience) is mediated by the complex array of coexisting organisms and their interactions. There is increasing evidence that the overwhelming majority of species in the phytobiome are involved in myriad interactions, both between individual microbes and with the plant host. Importantly, these pairwise interactions can be further mediated by the presence of other species and/or interactions. However, we have limited insight into the ways in which 
the biological organization of the holobiont, and its associated array of species interactions, impact phenotype. Moreover, we have little in the way of analytical, experimental, or conceptual frameworks for building this understanding.

Network analyses offer a useful starting point for exploring the biological organization of phytobiomes, by characterizing the relationships among species or operational taxonomic units within a community. Co-association networks have been widely used to describe plant microbiomes (Bakker et al. 2014; Poudel et al. 2016; Shi et al. 2016), partly because they can be readily created using amplicon sequencing data. Specifically, co-association networks identify pairs of species whose abundances are significantly correlated across space or time. Connections between species can represent positive or negative co-associations. Such networks provide a holistic perspective on the biological organization of the phytobiome, for example in quantifying community connectivity (the total number of associations within the community). Communities with low connectivity have few consistently co-associated species, suggesting either weak or inconsistent organization across the landscape, while high connectivity might suggest strong environmental determinants of community structure. In one study, community connectivity was reported to increase in rhizosphere microbiomes over the course of a growing season (Shi et al. 2016), implying an increasing role for microbiome community organization and consistent assembly dynamics as the season progresses.

It is critical to note also a significant limitation of co-association networks to understanding species interactions within the phytobiome. Species may coexist because of shared habitat preferences (passive co-association) or explicit species interactions (e.g., syntrophy, nutrient complementarity, or mutualisms). Analogously, species may be negatively correlated across phytobiomes because of distinct habitat preferences or due to direct antagonistic or competitive species interactions. Thus, positive or negative coassociations do not in themselves, per se, prove a role for species interactions in community assembly or functional characteristics (Freilich et al. 2018). Despite this limitation, co-association analyses have also been commonly used to define "modules," or collections of species that tend to have similar abundance profiles across samples.
Species interaction networks offer a more definitive means for evaluating the biological organization of individual communities. In recent research, we have mapped species resource competitive, antagonistic, and signaling interactions among microbial populations within individual holobionts. In contrast to co-association networks, interaction networks detail explicit pairwise competitive, inhibitory, or signaling interactions among populations (Fig. 1). Though the extent of such detailed pairwise interaction networks is limited by our ability and capacity for culturing isolates, these networks highlight the complexity of, and variation in, species interactions among plant microbiomes. For example, connectivity differs substantially among these three communities, but so does the distribution of interactions among species (Figs. 2 and 3).

By identifying specific microbial isolates that are either especially impacted by species interactions (high in-degree) or are dominant in impacting other species (high out-degree), we can also begin to characterize the roles occupied by specific microbes within the network (Figs. 2 and 3). Understanding the extent to which particular taxa are likely to be significantly engaged in species interactions, and which taxa are largely independent (noninteractive) is important to understanding the ways in which various taxa contribute to the aggregate phenotype. For example, highly interactive species within the microbiome may have little direct impact on the plant, but still play critical roles in determining phenotype due to their impacts on other organisms. For these species, microbiome composition may be especially critical to determining their impact on the phytobiome. In contrast, interaction-independent taxa may have consistent impacts on phenotype, regardless of the composition or relative abundances of other microbes in the phytobiome. Similarly, highly interactive pathogens may be more amenable to biological control than noninteractive pathogen populations.

Our goal in effective management of phytobiomes is to optimize holobiont phenotypes. The complexity of phytobiomes can be daunting, but network analyses offer an important tool for building our understanding of biological organization within the phytobiome, and a means for quantifying variation in community structure. Systematic evaluation of co-association and species interaction networks among phytobiomes are needed to shed light on the ways in which the biological organization of the phytobiome and its
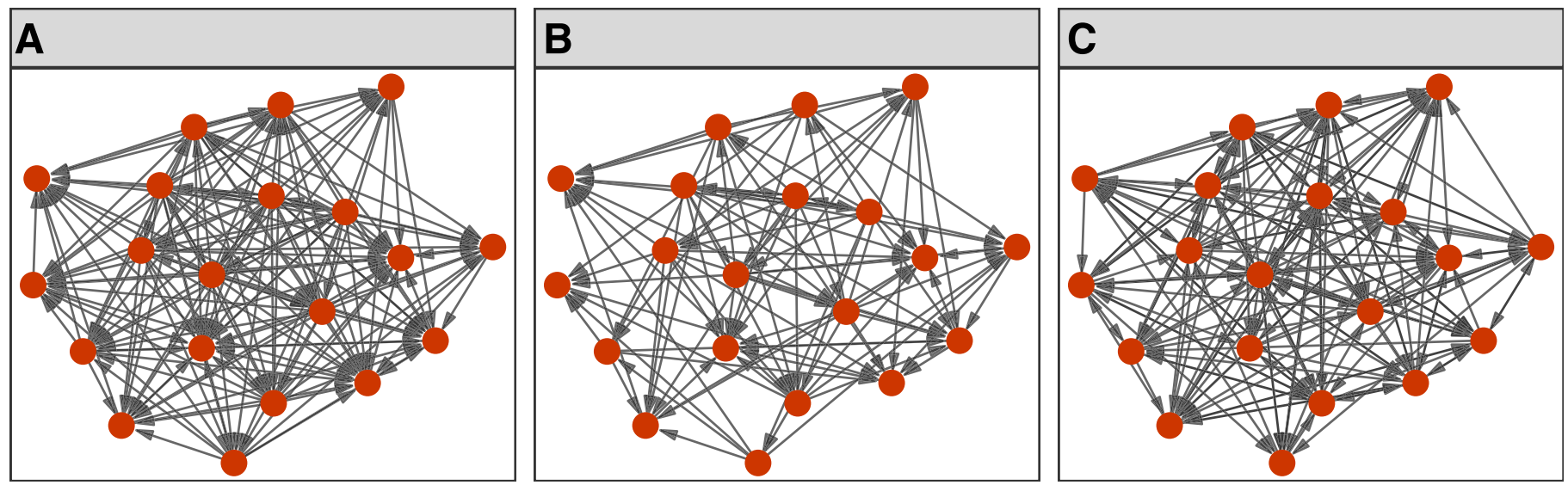

Fig. 1. A to C, Species interaction networks for three microbial communities. Each red circle represents an individual microbial isolate, and interactions between isolates are characterized here with directional arrows. Thus, for example, when considering inhibitory interactions (antibiosis), an arrow indicates the capacity of one isolate (the arrow source) to inhibit another isolate (the arrow head). Similarly, resource competition can be captured by arrows that identify capacities of isolates to consume some threshold proportion of another's resource niche space. Additional species interactions, including both directional and nondirectional interactions (e.g., signaling, syntrophy, and parasitic or mutualistic relationships) may also be summarized using networks. 

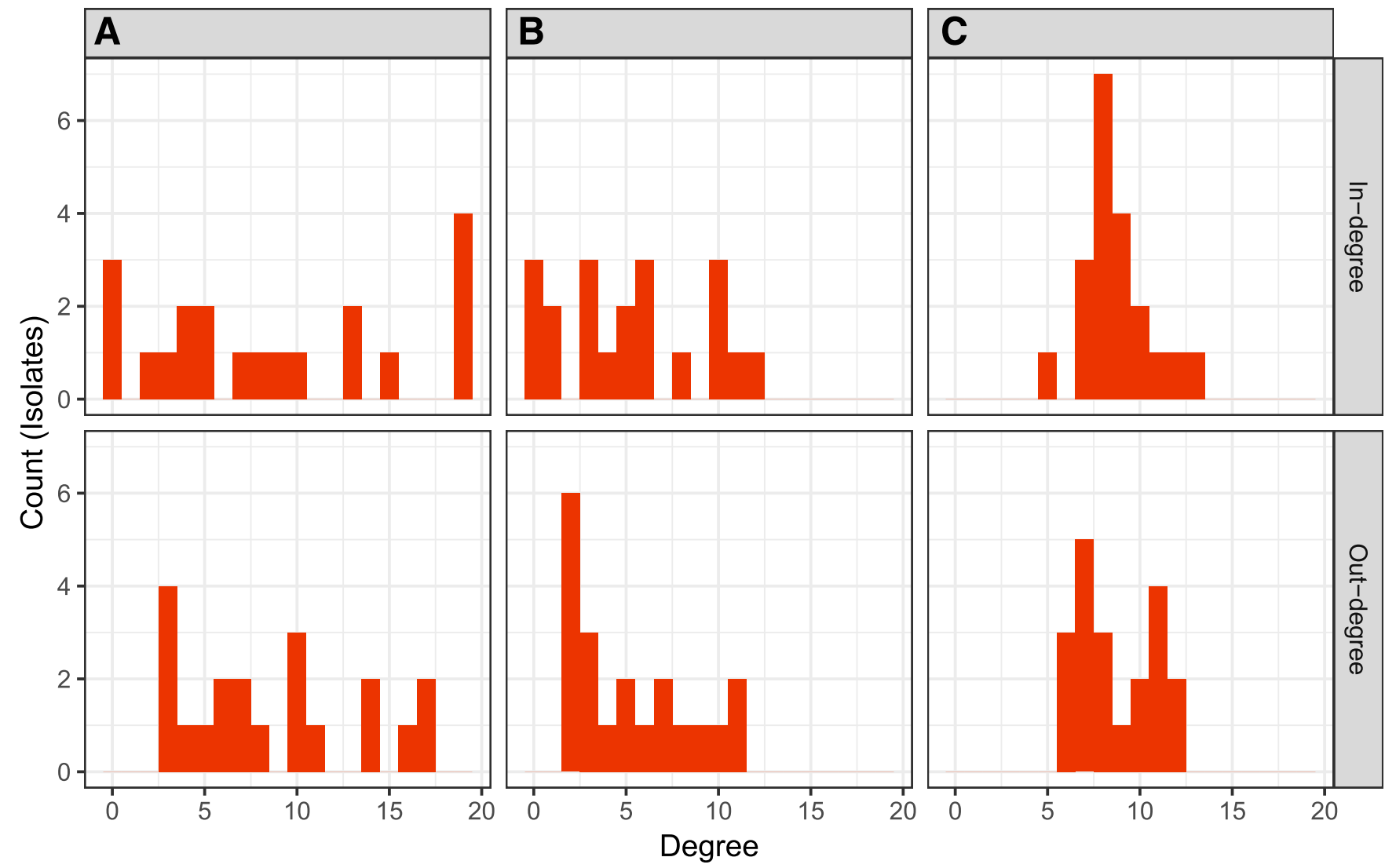

Fig. 2. A to C, Degree distribution for each of these three microbial communities. To generate the degree distribution, the number of connections each isolate has to other isolates within the community (the degree for an isolate) is first determined for every isolate. For directed interactions (e.g., inhibitory interactions illustrated here), every isolate has both outgoing interactions (out-degree, or the number of antibiotic targets) and incoming interactions (in-degree, or the number of organisms to which an isolate is susceptible). The distribution of in-degrees and out-degrees among isolates within a community sheds light on the different roles that individual isolates play within the community. For example, communities having greater abundance of isolates that have high out-degrees may be dominated by these "superkillers" that inhibit most other community members. Similarly, variation in the frequency of low versus high in-degrees among communities provides insight into the extent to which interactions are centered on a small number of highly sensitive isolates versus more broadly distributed among many moderately resistant isolates, facilitating inferences about functional diversity.
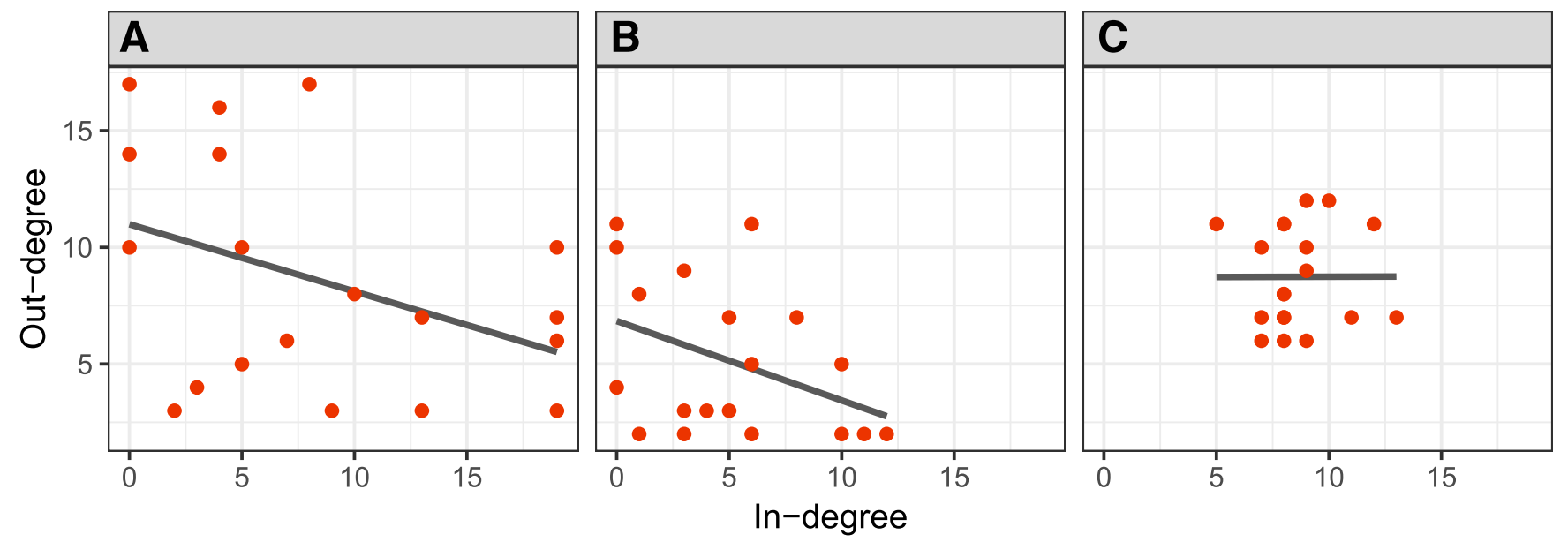

Fig. 3. A to C, Out-degrees versus in-degrees for every isolate in the same three communities. In these plots, each isolate is represented by a point whose position is dictated by the combination of incoming and outgoing connections. This allows for enhanced inference about specific isolates and their roles within the network. For instance, despite the visual similarity in their networks (Fig. 1), communities $A$ and $C$ have quite distinct relationships between in- and out-degrees among isolates, while those for networks $A$ and $B$ are highly similar. Communities $A$ and $B$ are composed of a range of highly inhibitory/highly resistant isolates (high out-degree/low in-degree) and weak inhibitory/low resistance (small out-degree/high in-degree), while community $\mathrm{C}$ is composed of isolates having more broadly similar resistance and inhibitory capacities. Variation in the strength and direction of out-degree versus in-degree relationships among communities provides a basis for quantifying differences in interaction structure among communities. 
array of species interactions impact phenotype, and provide a path toward effective management.

Epidemiological perspectives on scaling phytobiome evaluation/ network analysis

\section{Contributed by Karen Garrett and Ricardo I. Alcalá-Briseño}

Many concepts from epidemiology can inform phytobiome analyses, particularly when the focus is on pathogens, their vectors, and other microbes that interact with them. One key emphasis of epidemiology is dispersal, a challenge for understanding complete phytobiomes, where a wide range of mechanisms and scales of dispersal may be important. A second key component of epidemiology is integration of human decision-making and its influence on both small- and large-scale phytobiomes. Network analysis is a powerful tool for evaluating microbe dispersal and the spread of information among microbes, plants, and humans, with effects on decision-making across taxa and scales (Garrett 2012; Garrett et al. 2018). Networks of microbial taxon association can be used to identify candidate assemblages for biocontrol (Poudel et al. 2016). Global crop breeding networks describe the potential for human influence on the global dispersal of crop genotypes and associated phytobiomes (Garrett et al. 2017). In individual farmers' fields, particularly for resource-poor farmers who may have limited options for purchasing seed, an "integrated seed health strategy" can support decision-making about balanced use of quality-declared seed, crop resistance to disease, and on-farm management (ThomasSharma et al. 2017). Local networks of crop seed exchange, in combination with farmers' strategies, determine the final distribution of crop genotypes and pathogens, including the distribution of crop genes that select for particular microbiomes (Andersen et al. 2019; Buddenhagen et al. 2017).

\section{INCREASING FOCUS ON MACROORGANISMS IN THE PHYTOBIOME}

\section{Contribution of soil animals to soil microbiome function}

\section{Contributed by Kyle Wickings}

While microbes are acknowledged as the dominant driver of ecosystem processes in the rhizosphere, invertebrates can have both direct and indirect effects on rhizosphere processes through their interactions with microorganisms. Soil animals contribute directly to soil microbiome composition and function through the consumption of bacterial cells and fungal hyphae, and, through their movement, also aid in microbial dispersal throughout the soil profile and the colonization of new resources (Crowther et al. 2012; Lilleskov and Bruns 2005). Invertebrates also make a number of indirect contributions to soil microbial communities and processes including modification of the distribution and chemical composition along with the rate of introduction of new microbial resources in the soil profile and within soil aggregates (Chamberlain et al. 2006; Shuster et al. 2001; Wickings and Grandy 2011). These changes often stimulate microbial activity, increase community size, and alter community structure.

Interest in manipulating microbial communities for enhancing ecosystem services such as plant productivity, pest suppression, nutrient cycling, and soil organic matter formation warrants a more complete understanding of the biotic factors that govern microbial functioning in soils. Given the growing awareness of the importance of invertebrates as moderators of microbial function in the rhizosphere, it is critical that they be better integrated into the soil microbiome framework. For decades, soil ecologists have acknowledged that the effects of soil fauna on belowground ecosystem services stem both from their direct interaction with plant residues and their alteration of soil microbial communities (Seastedt 1984); however, direct and indirect effects of soil animals are difficult to distinguish experimentally. Consequently, the relative importance of animal-microbe interactions in governing microbial control of soil processes remains poorly understood, and such interactions require more attention in modern soil microbiome research. This knowledge gap will become increasingly relevant when attempting to manipulate microbiome traits in managed ecosystems receiving diverse plant, soil, and pest management practices, many of which are known to alter both microbial and animal communities belowground (Gan and Wickings 2017; Wickings and Grandy 2013). Such diversity in ecosystem management will be important to account for when predicting the functional output of soil microbiome manipulations in agricultural production systems.

\section{Modifying the composition and function of plant-associated arthropods}

\section{Contributed by Mary Barbercheck}

Arthropods comprise the largest and most varied group of invertebrates on Earth and are essential to ecosystem health. They contribute to many critical ecological processes, including decomposition, pollination, and predation. In agricultural and other managed ecosystems, some plant-feeding arthropods can become pests, which are estimated to cause a loss of about 18 to $26 \%$ of world crop production (Culliney 2014). The most widespread approach to controlling arthropod plant pests and associated losses in commercial agriculture is through the application of insecticides. Although the use of insecticides has contributed to agricultural productivity, the risks for negative nontarget impacts to the environment, humans, and other animals, including natural enemies of arthropods, and loss of efficacy through development of resistance, illustrate the need for integration of novel approaches to arthropod pest management (Damalas and Eleftherohorinos 2011; Squillace et al. 2002).

Alternative approaches to pesticide-intensive modification of arthropod community composition and function need to address ecological and organismal processes at multiple spatial and temporal scales, and their mediation by biotic and abiotic components of the environment and management practices (Begg et al. 2017). Two general factors in trophic interactions that drive populations of herbivorous arthropods that vary in relative strength among communities and ecosystems can be targeted for manipulation (Walker and Jones 2001). "Top-down" factors are those related to the action of natural enemies (e.g., predators, parasitoids, and pathogens) on plant-feeding arthropods, whereas "bottom-up" factors include those related to food quality (e.g., nutrient content or secondary metabolites) or supply. Approaches that combined top-down and bottom-up factors could improve efficacy of arthropod management strategies (Jaber and Ownley 2018; Peterson et al. 2016).

Top-down factors. At the field and landscape scale, manipulating the biotic and abiotic components of the environment to support populations and promote the efficacy of natural enemies of plantfeeding arthropods is the basis of conservation biological control (CBC) (Chaplin-Kramer et al. 2011; Tscharntke et al. 2008). To implement $\mathrm{CBC}$ to achieve predictable reductions of plant-feeding arthropods is complex, and focuses on habitat management to add diversity to resources that are limiting to natural enemies, e.g., shelter, nectar, alternate prey, or pollen, resulting in an increase in natural enemies for pest suppression (Begg et al. 2017; Letourneau et al. 2011). Common practices in CBC include reducing the use of broad-spectrum insecticides and increasing the diversity of floral and 
other plant-associated resources through cover crops and establishing edge or in-field plantings of floral resource plants (insectaries), beetle banks, and hedgerows. For example, the floral resource plant, sweet alyssum, Lobularia maritima (L.) Desv. (Brassicaceae), supported the suppression of aphids (Hemiptera: Aphididae) by the hoverfly, Eupeodes fumipennis (Thomson) (Diptera: Syrphidae) in California lettuce fields. The presence of alyssum enhanced hoverfly egg production, resulting in more hoverfly larvae and fewer aphids. Hoverfly survival was unaffected by alyssum, indicating that the effect of alyssum on aphids was mediated primarily through enhanced reproduction by the hoverfly (Hogg et al. 2011).

Bottom-up factors. Plants have evolved multiple defense strategies against herbivorous organisms, including arthropods (Erb et al. 2012; Johnson et al. 2016). A major defense against herbivory by arthropods involves chemical defenses, represented by constitutive or induced secondary metabolites (reviewed in Mithofer and Boland 2012). The phytohormones jasmonic acid and salicylic acid coordinate the complex signaling pathways involved in these multitrophic interactions (Pieterse et al. 2014; RobertSeilaniantz et al. 2011). Chemical defenses can be toxic, repellent, or antinutritive for herbivores directly, or they may affect herbivores indirectly via the attraction of natural enemies. Direct defenses include changes in plant nutrient profiles, production of toxins, digestion inhibitors, and herbivore-induced plant volatiles (HIPVs) (Johnson et al. 2013b; Kessler and Baldwin 2001; Turlings et al. 1990), and include compounds such as alkaloids, cyanogenic glycosides, glucosinolates, and terpenoids. HIPVs can be toxic to some members of the phytobiome, e.g., microbes and herbivorous arthropods (van der Meijden and Klinkhamer 2000), and therefore, can have complex effects on the phytobiome, with both positive and negative consequences for the plant (Poelman 2015).

In indirect defenses, plants under attack increase production of HIPVs that can be used by predators as cues for locating their herbivore prey (Khan et al. 2008; Poveda et al. 2010). For example, above-ground egg deposition by stemborer moths, Chilo partellus, on corn was associated with emission of HIPVs that attracted the egg parasitoid, Trichogramma bournieri, and the larval parasitoid, Cotesia sesamiae (Tamiru et al. 2012). The authors suggested that these results implied a sophisticated defense strategy whereby plants recruit parasitoids in anticipation of egg hatching. In another example, the volatile sesquiterpene $(E)$-caryophyllene serves as a signal involved in plant defense against below-ground herbivorous arthropods (Rasmann et al. 2005; Tamiru et al. 2012). Roots of some varieties of corn release caryophyllene in response to feeding by larvae of the Western corn rootworm, Diabrotica virgifera virgifera, a beetle pest of corn. This compound attracts a natural enemy of rootworms, the entomopathogenic nematode, Heterorhabditis megidis. Field experiments showed a fivefold higher nematode infection rate of $D$. $v$. virgifera larvae on a corn variety that produced the signal compared with a variety that did not (Rasmann et al. 2005).

Root-associated microbes, including symbiotic fungi such as mycorrhizae and endophytes, may trigger physiological changes in the host plant that induce systemic host plant defenses and influence interactions between plants and aboveground insects at several trophic levels, including herbivores, predators and parasitoids (Pangesti et al. 2013; Pineda et al. 2017; Pineda et al. 2013). An interesting example is the interaction between fungi historically described as entomopathogens that can also grow as endophytes in a variety of host plants, where they function as antagonists of herbivorous arthropods and plant pathogens (Jaber and Ownley 2018), plant growth promoters (Bamisile et al. 2018; Sasan and Bidochka 2012), and rhizosphere colonizers (Hu and St. Leger 2002; PavaRipoll et al. 2011; St. Leger 2008). The negative effects of endophytic fungal entomopathogens on herbivorous arthropods have been attributed to induced systemic plant resistance (Akello and Sikora 2012; Lopez and Sword 2015; Lopez et al. 2014; Martinuz et al. 2012). The suggested mode of action for antagonism of herbivorous arthropods is feeding deterrence or antibiosis due to fungal metabolites secreted in planta (Akello et al. 2008; Akutse et al. 2013; Golo et al. 2014; Gurulingappa et al. 2010; Mantzoukas et al. 2015; Mutune et al. 2016; Muvea et al. 2014; Rios-Moreno et al. 2016); however, studies have not examined specific mechanisms for induced resistance associated with endophytic entomopathogens.

Several questions remain to be answered to improve our ability to manipulate plants, the phytobiome, and their environment to enhance beneficial processes (e.g., biological control) and reduce herbivory and losses of yield and quality. Can we breed for plant volatiles to improve plant resistance against key pests directly (bottom-up) and indirectly via improved biological control (top-down)? What are the roles of rhizosphere organisms and endophytes in mediating arthropod interactions with other arthropods and plants? What is the role of rhizosphere competency and in planta competitiveness in the establishment of plant-protective endophytic microbes by seed or soil inoculation? How do crop cultivars, soil types, microclimates, agronomic practices, and the presence of other organisms, including other herbivores, endophytes, plant pathogens, omnivores, and predators affect the establishment of beneficial organism(s) (Rosenheim et al. 2011; Wani et al. 2015)? Can we breed plants to modify the phytobiome to alter the quality of hosts for multiple herbivorous arthropods and produce herbivore-induced HIPVs that are cues for natural enemies (Douglas 2015; Stam et al. 2014; Zhu et al. 2014b)? Should the development of plant-protective microbes focus on individual species or compatible consortia of microorganisms? Can we alter the phytobiome to simultaneously manage pests and pathogens (Pineda et al. 2017)?

\section{The role of host plant genetics in shaping phytobiomes}

\section{Contributed by John Carlson}

Improving plant climatic resilience, food-fiber-fuel production and ecosystem sustainability in concert, requires a phytobiomesbased systems biology approach that considers all factors that influence plant growth and productivity (Busby et al. 2017). A plant's genotype plays a major role in shaping plant growth and productivity. However, whether in highly managed agricultural cropping (eco)systems or in unmanaged natural ecosystems, plant growth and productivity are the result of highly complex gene networks and genotype-by-environment interactions (Stuber 1994).

Plant growth and productivity are complex multigenic traits, with each of the many genes involved across the genome exerting only minor control on each trait. Complex trait variation is typically then "quantitative," in which natural populations display a normal distribution of phenotypic values resulting from the contributions of varying accumulations of alleles for the many genes involved (Stuber 1994). Complex traits tend to have lower heritability than simple gene-for-gene traits, i.e., performance differs among generations and different conditions. Low heritability in complex trait phenotypes is in large part because the many underlying genes respond differently to different environmental conditions (Eversole 2016). Thus complex traits reflect both the underlying genotypic variation and the environment in which the genes were expressed.

We now have the means to efficiently and comprehensively catalog genotypes of individual plants by whole genome sequencing. However, pinning down all factors in the environmental variables in the phenotype $=$ genotype $\times$ environment equation for complex plant phenotypes like yield has remained elusive (Busby et al. 2017; Eversole 2016).

In practice, natural selection and breeding (artificial selection) succeed in improving mean growth and productivity of crops by shaping (matching) factors, such as composition and function of the 
microbial community with each plant's genotypes. To shape phytobiomes, we will need to decipher the many interactions of genotype and environment at a more comprehensive, systems level. Experimentally, this will require studies that compare replicates of multiple genotypes at multiple sites differing environmentally, over multiple years and generations. Fortunately, this is what quantitative geneticists (breeders) do. They have provided a rich literature, data collections, and even long-term field trials for perennial crops, documenting the genetic contributions to phenotypes in many crops and tree species from past and ongoing breeding activities.

Furthermore, the field of ecological genomics is contributing important insights into the profound effects from a community genetics perspective of the genotype of host plants on shaping multitrophic interactions of perennial plants, such as trees, with other organisms such as herbivores and symbionts (Keith et al. 2010; Ungerer et al. 2008). In exchange, a holistic understanding of phytobiomes should strengthen the predictive value of breeding and quantitative ecosystem models (Singh et al. 2018; Stewart et al. 2018). To achieve a comprehensive understanding of phytobiomes for improving crop productivity, it will be necessary to include the effect of the host plant's genotype on shaping, and elucidating, the important factors influencing genetic-by-environment interactions (Busby et al. 2017).

\section{PHYTOBIOME MANIPULATION BEYOND AGRICULTURAL PRODUCTION}

\section{Postharvest management of crop microbiomes}

\section{Contributed by Jasna Kovac, Taejung Chung, and Xiaoqing Tan}

Understanding the taxonomic composition and functional role of postharvest crop microbiomes is essential for enhancement of the quality and safety of plant foods (Bokulich et al. 2016). Early challenges with the sensitivity of direct metagenomic sequencing for detecting low-abundant microbial taxa of interest relevant to plant food quality and safety have led to a paradigm shift in approaches to microbial hazard detection. As opposed to direct detection of low abundance pathogens of interest, changes to microbiomes in which pathogens and spoilage microorganisms commonly occur are beginning to be explored. Detection of such microbiome perturbations requires a baseline database of microbiomes and their transcriptomes in samples collected throughout the food supply chain. These are being cataloged by the Sequencing the Food Supply Chain consortium led by the International Business Machines (IBM) Corporation, in collaboration with other industry and academic partners, among others (Fontanazza 2016).

Development of new methods, and optimization of existing methods, for characterization of plant food supply microbiomes is leading to a better understanding of microbial ecology at different stages in the food supply chain (Bokulich et al. 2016; Busby et al. 2017; Jarvis et al. 2015; Lebeis 2014; Leff and Fierer 2013; Rossouw and Korsten 2017). Relating microbiome composition to function, and identifying factors influencing function, is the first step toward shaping agricultural pre- and postharvest microbiomes for increased food quality and safety. However, several challenges remain to be overcome. As in any system, the key influential environmental and anthropogenic factors shaping microbiomes need to be identified (Fig. 4). Second, identified factors need to be categorized based on the ability to control or manage them by changing preharvest agricultural and postharvest food processing practices. A number of environmental factors are impacted by anthropogenic activities (e.g., air, weather, soil, and plant surface), but not all can be practically managed. For example, the air microbiome has been shown to overlap with the plant phyllosphere microbiome, but cannot be readily controlled in the field (Ottesen et al. 2016). Nevertheless, there is great potential in controlling soil and plant microbiomes that serve as inocula for built postharvest crop processing environments.

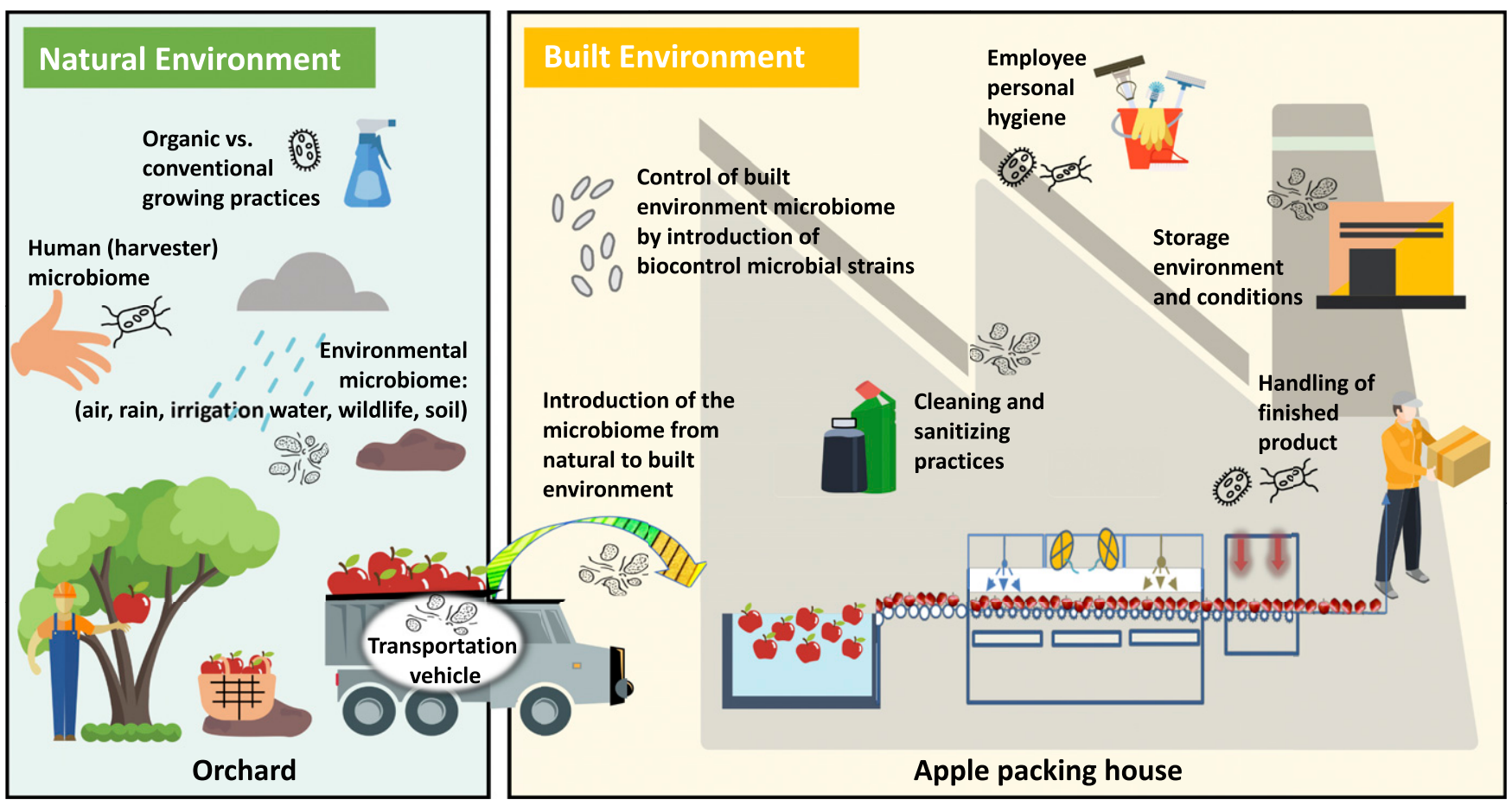

Fig. 4. Potential factors in natural and built environments that may shape food crop microbiomes. This illustration is based on an apple supply chain, but represents the type of interactive processes that govern microbial flow between environments and/or management stages, as well as the factors that constrain microbiome composition. Here, environmental and anthropogenic factors are influencing microbiome composition on food crops throughout the food supply continuum. This includes natural environments in the preharvest chain and built environments in the postharvest chain. 
Postharvest environment microbiomes are typically managed through physical and chemical cleaning and sanitizing procedures. These procedures, even though controlled, often fail to control pathogens such as Listeria monocytogenes that are commonly associated with fresh produce outbreaks (Angelo et al. 2017; Garner and Kathariou 2016). The difficulties in effective cleaning and sanitizing of poorly accessible parts of built environments are recognized as the main cause of foodborne pathogen persistence in these environments; often in biofilms (Colagiorgi et al. 2017). Food safety challenges associated with produce supply chain are driving a new wave of research focused on investigating the protective potential of microbial biocontrol strains. Manipulations of postharvest food processing environments, with the goal of pathogen exclusion, have been successfully demonstrated in the animal food supply chain (Zhao et al. 2013), but are yet to be assessed in plant processing environments. Going forward, these types of control agents will likely need to be carefully tailored to allow for their successful growth and competition with the baseline microbiomes under specific environmental conditions (e.g., different temperatures, humidity levels, and surface materials).

\section{Can microbial intervention be used as a strategy to manage invasive plants?}

\section{Contributed by Kurt Kowalski}

Invasive plants are a global problem, including in highly valued coastal and wetland systems. As nonnative plants (e.g., common reed in the Great Lakes system; Phragmites australis (Cav.) Trin. ex Steud.) invade, they often displace native flora, reduce biodiversity, degrade fish and wildlife habitat, reduce recreational opportunities, increase fire hazards, and decrease property values (Great Lakes Phragmites Collaborative 2018; Isely et al. 2017; Weinstein and Balletto 1999). Therefore, resource managers invest substantial time and resources in management and control (Braun et al. 2016; Hazelton et al. 2014), often with little long-term success (Martin and Blossey 2013). Similarly, the agricultural industry is seeking new ways to control weeds (often nonnative) sustainably and maximize crop growth. However, the underlying biological mechanisms that help invasive plants outcompete native plants, or improve the yield of agricultural crops, are not clear.

We know that microbes (e.g., bacteria, fungi, and oomycetes) exist in soil, water, on plants, and in plants during all growth stages. We also know that $P$. australis and other invasive plants host a tremendous diversity of endophytic microbes (Bickford et al. 2018; Bowen et al. 2017; Clay et al. 2016; Reinhart and Callaway 2006; Shearin et al. 2018; Soares et al. 2016), both in their native range and introduced range. Microbes are known to form symbiotic relationships with plants that generate many plant benefits, including increased tolerance to heat, drought, and other stresses, accelerated development of seedlings, and increased growth and yield (de Vrieze 2015). Further, plants can manipulate the microbiome to influence the local environment (Bowen et al. 2017; Funck-Jensen and Hockenhull 1984; White et al. 2018) and create conditions that support enhanced growth. Increased stress tolerance and growth characteristics are, in part, why nonnative plants can be so invasive on the landscape.

The symbiotic relationships among microbes and plants, therefore, can be targeted for disruption or enhancement, depending on the purpose of the management actions (Kowalski et al. 2015). Once microbial composition is characterized and the roles of individual microbes are known, new techniques can be developed to disrupt symbiotic relationships and decrease the benefits that they generate for invasive plants (Kennedy 2018; Kowalski et al. 2015), or alternately, promote microorganisms that negatively impact invasive plant health and abundance. Similarly, symbiotic relationships that promote growth in native species, agricultural crops, or desired species can be targeted for enhancement. Combining these two approaches may generate innovative treatments that combat invasive plant growth while promoting growth of desirable species. Advancements in research to identify the microbes in invasive plants of aquatic and terrestrial systems, and the roles that they play in growth and production, are leading to exciting new approaches for invasive species management, habitat restoration, and agricultural production.

\section{PRACTICAL AND SOCIAL CONSIDERATIONS FOR PHYTOBIOME MANIPULATION}

\section{Communicating phytobiome management to stakeholders and consumers}

\section{Contributed by Jessica Myrick}

Phytobiome scientists are eager to avoid public misconceptions and potential politicization of their work, similar to what has occurred with genetically modified organisms. It may be tempting to suppose that simply communicating more frequently about phytobiome science will prevent stakeholders and the public from misunderstanding the science. Nonetheless, facts alone are often not enough. It used to be a common assumption that if scientists could educate the public and remove any knowledge deficits that existed, then people would accept the science and act in line with it. However, research science communication shows this "deficit model" does not hold up to empirical scrutiny (National Academies of Sciences Engineering and Medicine 2017). This does not mean that facts cannot help shift attitudes; however, it does mean that when communicating information about the phytobiome, scientists need to keep in mind the goals and motivations of different audiences.

The empirical study of and media effects offers phytobiome scientists some strategies for more effectively sharing their research with stakeholders and consumers. For example, using stories or narrative structures communication is more engaging than listing facts alone (Dahlstrom 2014). The story could be the researcher's path to the topic, the narrative of how the study came to be and then progressed, the tale of the study of the phytobiome more generally, or even a single plant's "story."

Consider using emotionally evocative content strategically, but not just fear. When people become really scared, many tune out and avoid the topic at hand. Think about ways to talk about solutions to pressing phytobiome issues in order to leave audiences with something hopeful to ponder that can then motivate them to further engage with the topic (Nabi and Myrick 2018). Curiosity is another key driver for why people seek science news (Shearer 2018), one that could also help increase interest in the phytobiome. Awe and wonder about the natural world are also powerful drivers of attention and action (Keltner and Haidt 2003), ones which phytobiome scientists could harness for conveying the importance of their research to stakeholders and the public.

\section{Hurdles to adopting new production practices}

Contributed by Alyssa Collins, Paul Esker, Beth Gugino, and Kari Peter

Although research can identify promising new strategies for phytobiome management, this is not enough for widespread implementation. Farmers/growers consider a number of factors when deciding whether to adopt a new technology, including the 
following. (i) Does the technology address a farmer-based need or perceived need? (ii) What is the cost? (iii) How easily can it be integrated with existing farming practices and equipment? And (iv) how will it improve production in the short and long term? Farmers must weigh both immediate and long-term benefits, and the importance of each will vary based on the financial security and cropping system(s) of each farmer. Additionally, new approaches are unlikely to work equally across different cropping systems and farm scales. Since profit margins also vary by crop type, an approach may be technically feasible across systems, but only economically feasible in some.

Adoption of new technologies is largely impacted by attitudes of farmers toward new technology (Mase et al. 2017), i.e., where they lie on the technology adoption curve, as well as whether or not their consumer market will accept the technology. Late adopters are unlikely to make a change without substantial precedent in the farming community, even if shown the benefits of a new technology. Those working to bridge research and practice, such as extension educators, aim to identify early innovators, who can then help to diffuse technology to other farmers. Concepts should be easily communicated through this route, as individual farmers will aim to innovate and adapt new approaches within their personal operation scheme and production constraints.

Farmers are cognizant of the fact that there are no silver bullets, and this should be considered in communication. Agricultural practices are meant to be integrated, with additive and/or synergistic impacts on crop health. Farmers are also seeking consistency in production benefits, which leads to predictability in year-to-year yields. For example, it would generally be preferable to see an incremental productivity or profit increase in nine out of ten growing years, as opposed to a large increase in one or two. In addition to the predictability of management impacts, cost-benefit tradeoffs, ease of adoption, and consumer acceptance of the technology are primary concerns of farmers when considering new approaches or technologies.

\section{Thinking about social innovation as agricultural scientists}

\section{Contributed by Leland Glenna and Maria Fernanda Vivanco Salazar}

The likelihood that phytobiome research will contribute to public wellbeing is contingent on the social context in which the research is conducted and diffused. In the United States, agricultural research and development policies and research funding since the late 1970s and early 1980s has focused on generating private goods and attracting private research investments (Glenna et al. 2015). Research indicates that this privatization approach to agricultural research and development has failed to generate the promised public benefits (Glenna et al. 2015; Heisey and Fuglie 2018; Lopez and Galinato 2007).

The social innovation concept emerged after analysts came to realize that privatization failed to deliver widespread social benefits from science and technology research (Moulaert et al. 2013). Rejecting the idea that society is best coordinated through selfregulating markets, social innovation proponents claim that direct policy interventions, institutional change, and other collective actions are necessary to achieve socially equitable outcomes (Jessop et al. 2013). This leads to the question of whether university research is likely to contribute to social innovation.

We conducted a survey of 1126 agricultural scientists at 71 United States land-grant universities and analyzed how scientists perceive their research activities contributing to social innovation. The survey measured scientist norms, beliefs, and values regarding how they envision science and technology contributing to social outcomes and how their perspectives relate to their research activities and outputs. Principle components analysis divided scientists into two factors: private-science norms and public-science norms. Since just over one-third of respondents agreed or strongly agreed with the statement that scientists should focus on research with market potential and about two-thirds agreed or strongly agreed that scientists should focus on research with public benefits, it is reasonable to conclude that approximately one-third of scientists adhere to privatescience norms and two-thirds adhere to public-science norms. Additional statistical analysis found that those conforming to the private-science factor were significantly more likely than those conforming to the public-science factor to be correlated with the belief that markets are best able to evaluate the social value of science and technology and that markets are best at solving social problems like hunger. The private-science factor was also significantly correlated with less basic science research, with industry funding and industry collaborations, and with more excludable research outputs.

The findings have implications for national, state, and university policies directed at promoting social innovations from universitybased agricultural research. Traditionally, university scientists have been expected to conduct basic research, to generate public goods, and to be dedicated to solving social problems that are not easily addressed with a commercial product. If one-third of public agricultural scientists are committed to private-science norms and practices, the capacity for land-grant universities to contribute the public goods needed to solve social problems will likely be compromised.

\section{CONCLUSIONS}

Both wild and tamed phytobiomes have been modified by humans for centuries, but without an understanding of how most components of the system were being changed or impacting plant growth. The goal of phytobiome modification, as discussed here and in our symposium, is to understand how the many elements of the phytobiome interact, and how specific management of previously ignored factors can help to meet societal needs.

A discussion within a larger group in our workshop identified many potential challenges to phytobiome manipulation, encompassing scientific, practical, and social barriers. Within each of these three categories, numerous factors could feasibly be modified (e.g., crop varieties, microorganisms, public, and grower engagement), whereas many others could not, at least in the short term (e.g., soil type and culturally driven norms). Phytobiome science encourages a systems view of plant production and management, and yet not all components of the system present effective management targets. An important near-term goal for this field should be to estimate the potential relative contribution and mutability of distinct phytobiome components. Such estimations should consider both the physical limitations and the practical/social constraints on management change.

Effective phytobiome management will depend on integrating scientific advances with farming, management, and/or societal realities; this presents opportunities for innovative and creative thinking. An important step in this nascent field of science is to identify research directions that have a high potential for impacting the health and productivity of our natural and managed landscapes in the face of our currently limited understanding of the complex interactions within phytobiomes and the level of specificity of these interactions to distinct biomes and plant species. Given this complexity, inter- and crossdisciplinary communication across phytobiome researchers, and broadening of the disciplines working in this field, will help maximize innovation. Ultimately, the health of our environment and the productivity of our agricultural enterprise require a new approach to managing both wild and natural phytobiomes into the future. 


\section{ACKNOWLEDGMENTS}

We thank J. Drohan for recording notes during the workshop, which contributed to the structuring of this manuscript. We also thank all workshop and symposium participants for insightful discussions on these and other topics that came up during the event. Funding support for the Wild and Tamed Phytobiomes Symposium was provided by Penn State University, through the College of Agriculture, Eberly College of Science, and the Huck Institutes of the Life Sciences, with additional funding support from WrightLabs, Pall Laboratory, Pacific Biosciences, and NewLeaf Symbiotics. Any use of trade, firm, or product names is for descriptive purposes only and does not imply endorsement by the U.S. Government.

\section{LITERATURE CITED}

Abdalla, M. A., Sulieman, S., and Mcgaw, L. J. 2017. Microbial communication: A significant approach for new leads. S. Afr. J. Bot. 113:461-470.

Adams, I. P., Miano, D. W., Kinyua, Z. M., Wangai, A., Kimani, E., Phiri, N., Reeder, R., Harju, V., Glover, R., Hany, U., Souza-Richards, R., Nath, P. D., Nixon, T., Fox, A., Barnes, A., Smith, J., Skelton, A., Thwaites, R., Mumford, R., and Boonham, N. 2013. Use of next-generation sequencing for the identification and characterization of maize chlorotic mottle virus and sugarcane mosaic virus causing maize lethal necrosis in Kenya. Plant Pathol. 62:741-749.

Adams, M. J., Antoniw, J. F., and Fauquet, C. M. 2005. Molecular criteria for genus and species discrimination within the family Potyviridae. Arch. Virol. 150:459-479.

Akello, J., Dubois, T., Coyne, D., and Kyamanywa, S. 2008. Effect of endophytic Beauveria bassiana on populations of the banana weevil, Cosmopolites sordidus, and their damage in tissue-cultured banana plants. Entomol. Exp. Appl. 129:157-165.

Akello, J., and Sikora, R. 2012. Systemic acropedal influence of endophyte seed treatment on Acyrthosiphon pisum and Aphis fabae offspring development and reproductive fitness. Biol. Control 61:215-221.

Akutse, K. S., Maniania, N. K., Fiaboe, K. K. M., Van den Berg, J., and Ekesi, S. 2013. Endophytic colonization of Vicia faba and Phaseolus vulgaris (Fabaceae) by fungal pathogens and their effects on the life-history parameters of Liriomyza huidobrensis (Diptera: Agromyzidae). Fungal Ecol. 6:293-301.

Ali, S., Charles, T. C., and Glick, B. R. 2017. Endophytic phytohormones and their role in plant growth promotion. Pages 89-105 in: Functional Importance of the Plant Microbiome. S. Doty, ed. Springer International Publishing, Cham.

American Phytopathological Society. 2015. Phytobiomes: A roadmap for research and translation. www.phytobiomes.org/Roadmap/Documents/ PhytobiomesRoadmap.pdf

Amundson, R., Berhe, A. A., Hopmans, J. W., Olson, C., Sztein, A. E., and Sparks, D. L. 2015. Soil and human security in the 21 st century. Science 348 : 1261071.

Andersen, K. F., Buddenhagen, C. E., Rachkara, P., Gibson, R., Kalule, S., Phillips, D., and Garrett, K. A. 2019. Modeling epidemics in seed systems and landscapes to guide management strategies: The case of sweetpotato in Northern Uganda. Phytopathology.

Angelo, K. M., Conrad, A. R., Saupe, A., Dragoo, H., West, N., Sorenson, A., Barnes, A., Doyle, M., Beal, J., Jackson, K. A., Stroika, S., Tarr, C., Kucerova, Z., Lance, S., Gould, L. H., Wise, M., and Jackson, B. R. 2017. Multistate outbreak of Listeria monocytogenes infections linked to whole apples used in commercially produced, prepackaged caramel apples: United States, 2014-2015. Epidemiol. Infect. 145:848-856

Auchtung, J. M., Robinson, C. D., and Britton, R. A. 2015. Cultivation of stable, reproducible microbial communities from different fecal donors using minibioreactor arrays (MBRAs). Microbiome 3:42.

Bacon, C. W. 1995. Toxic endophyte-infected tall fescue and range grasses: Historic perspectives. J. Anim. Sci. 73:861-870.

Bakker, M. G., Schlatter, D. C., Otto-Hanson, L., and Kinkel, L. L. 2014. Diffuse symbioses: Roles of plant-plant, plant-microbe and microbe-microbe interactions in structuring the soil microbiome. Mol. Ecol. 23:1571-1583.

Bamisile, B. S., Dash, C. K., Akutse, K. S., Keppanan, R., and Wang, L. D. 2018. Fungal endophytes: Beyond herbivore management. Front. Microbiol. 9:544.
Beck, P. A., Gunter, S. A., Lusby, K. S., West, C. P., Watkins, K. B., and Hubbell, D. S. 2008. Animal performance and economic comparison of novel and toxic endophyte tall fescues to cool-season annuals. J. Anim. Sci. 86: 2043-2055.

Begg, G. S., Cook, S. M., Dye, R., Ferrante, M., Franck, P., Lavigne, C., Lovei, G. L., Mansion-Vaquie, A., Pell, J. K., Petit, S., Quesada, N., Ricci, B., Wratten, S. D., and Birch, A. N. E. 2017. A functional overview of conservation biological control. Crop Prot. 97:145-158.

Berendsen, R. L., Pieterse, C. M. J., and Bakker, P. A. H. M. 2012. The rhizosphere microbiome and plant health. Trends Plant Sci. 17:478-486.

Berthrong, S. T., Buckley, D. H., and Drinkwater, L. E. 2013. Agricultural management and labile carbon additions affect soil microbial community structure and interact with carbon and nitrogen cycling. Microbiol. Ecol. 66: $158-170$.

Bickford, W. A., Goldberg, D. E., Kowalski, K. P., and Zak, D. R. 2018. Root endophytes and invasiveness: No differences between native and non-native Phragmites in the Great Lakes Region. Ecosphere 9:e02526.

Bokulich, N. A., Lewis, Z. T., Boundy-Mills, K., and Mills, D. A. 2016. A new perspective on microbial landscapes within food production. Curr. Opin. Biotechnol. 37:182-189.

Bowen, J. L., Kearns, P. J., Byrnes, J. E. K., Wigginton, S., Allen, W. J., Greenwood, M., Tran, K., Yu, J., Cronin, J. T., and Meyerson, L. A. 2017. Lineage overwhelms environmental conditions in determining rhizosphere bacterial community structure in a cosmopolitan invasive plant. Nat. Commun. 8:433.

Bowsher, A. W., Kearns, P. J., and Shade, A. 2018. 16S rRNA:rDNA ratios and cell activity staining reveal consistent patterns of soil microbial activity. bioRxiv 435925. doi: https://doi.org/10.1101/435925.

Boyko, V., Ferralli, J., Ashby, J., Schellenbaum, P., and Heinlein, M. 2000. Function of microtubules in intercellular transport of plant virus RNA. Nat. Cell Biol. 2:826-832.

Braun, H. A., Kowalski, K. P., and Hollins, K. 2016. Applying the collective impact approach to address non-native species: A case study of the Great Lakes Phragmites Collaborative. Biol. Invasions 18:2729-2738.

Buddenhagen, C. E., Nopsa, J. F. H., Andersen, K. F., Andrade-Piedra, J., Forbes, G. A., Kromann, P., Thomas-Sharma, S., Useche, P., and Garrett, K. A. 2017. Epidemic network analysis for mitigation of invasive pathogens in seed systems: Potato in Ecuador. Phytopathology 107:1209-1218.

Busby, P. E., Soman, C., Wagner, M. R., Friesen, M. L., Kremer, J., Bennett, A., Morsy, M., Eisen, J. A., Leach, J. E., and Dangl, J. L. 2017. Research priorities for harnessing plant microbiomes in sustainable agriculture. PLoS Biol. 15:e2001793.

Calderón, K., Spor, A., Breuil, M. C., Bru, D., Bizouard, F., Violle, C., Barnard, R. L., and Philippot, L. 2016. Effectiveness of ecological rescue for altered soil microbial communities and functions. ISME J. 11:272-283.

Caldwell, B. A., Jumpponen, A., and Trappe, J. M. 2000. Utilization of major detrital substrates by dark-septate, root endophytes. Mycologia 92:230-232.

Canto, T., Aranda, M. A., and Fereres, A. 2009. Climate change effects on physiology and population processes of hosts and vectors that influence the spread of hemipteran-borne plant viruses. Glob. Change Biol. 15:1884-1894.

Castrillo, G., Teixeira, P. J. P. L., Paredes, S. H., Law, T. F., de Lorenzo, L., Feltcher, M. E., Finkel, O. M., Breakfield, N. W., Mieczkowski, P., Jones, C. D., Paz-Ares, J., and Dangl, J. L. 2017. Root microbiota drive direct integration of phosphate stress and immunity. Nature 543:513-518.

Chamberlain, P. M., McNamara, N. P., Chaplow, J., Stott, A. W., and Black, H. I. J. 2006. Translocation of surface litter carbon into soil by Collembola. Soil Biol. Biochem. 38:2655-2664.

Chaplin-Kramer, R., O’Rourke, M. E., Blitzer, E. J., and Kremen, C. 2011. A meta-analysis of crop pest and natural enemy response to landscape complexity. Ecol. Lett. 14:922-932.

Chavez-Calvillo, G., Contreras-Paredes, C. A., Mora-Macias, J., Noa-Carrazana, J. C., Serrano-Rubio, A. A., Dinkova, T. D., Carrillo-Tripp, M., and SilvaRosales, L. 2016. Antagonism or synergism between papaya ringspot virus and papaya mosaic virus in Carica papaya is determined by their order of infection. Virology 489:179-191.

Cheng, W. X., Parton, W. J., Gonzalez-Meler, M. A., Phillips, R., Asao, S., McNickle, G. G., Brzostek, E., and Jastrow, J. D. 2014. Synthesis and modeling perspectives of rhizosphere priming. New Phytol. 201:31-44.

Claflin, S. B., Jones, L. E., Thaler, J. S., and Power, A. G. 2017. Crop-dominated landscapes have higher vector-borne plant virus prevalence. J. Appl. Ecol. 54: 1190-1198.

Clay, K., Shearin, Z. R. C., Bourke, K. A., Bickford, W. A., and Kowalski, K. P. 2016. Diversity of fungal endophytes in non-native Phragmites australis in the Great Lakes. Biol. Invasions 18:2703-2716. 
Colagiorgi, A., Bruini, I., Di Ciccio, P. A., Zanardi, E., Ghidini, S., and Ianieri, A. 2017. Listeria monocytogenes biofilms in the wonderland of food industry. Pathogens 6:41.

Coleman-Derr, D., and Tringe, S. G. 2014. Building the crops of tomorrow: Advantages of symbiont-based approaches to improving abiotic stress tolerance. Front. Microbiol. 5:283.

Crowther, T. W., Boddy, L., and Jones, T. H. 2012. Functional and ecological consequences of saprotrophic fungus-grazer interactions. ISME J. 6: 1992-2001.

Cuevas, J. M., Delaunay, A., Visser, J. C., Bellstedt, D. U., Jacquot, E., and Elena, S. F. 2012. Phylogeography and molecular evolution of potato virus Y. PLoS One 7:e37853.

Culliney, T. 2014. Crop losses to arthropods. Pages 201-225 in: Integrated Pest Management Reviews. D. Pimentel and R. Peshin, eds. Springer, Dordrecht.

Dahlstrom, M. F. 2014. Using narratives and storytelling to communicate science with nonexpert audiences. Proc. Natl. Acad. Sci. USA 111: 13614-13620.

Damalas, C. A., and Eleftherohorinos, I. G. 2011. Pesticide exposure, safety issues, and risk assessment indicators. Int. J. Environ. Res. Public Health 8: 1402-1419.

Daryanto, S., Wang, L. X., and Jacinthe, P. A. 2017. Global synthesis of drought effects on cereal, legume, tuber and root crops production: A review. Agric. Water Manage. 179:18-33.

de Vrieze, J. 2015. The littlest farmhands. Science 349:680-683.

Delgado-Baquerizo, M., Grinyer, J., Reich, P. B., and Singh, B. K. 2016. Relative importance of soil properties and microbial community for soil functionality: Insights from a microbial swap experiment. Funct. Ecol. 30: 1862-1873.

Della Monica, I. F., Saparrat, M. C. N., Godeas, A. M., and Scervino, J. M. 2015. The co-existence between DSE and AMF symbionts affects plant P pools through P mineralization and solubilization processes. Fungal Ecol. 17:10-17.

Demers, J. E., Gugino, B. K., and Jimenez-Gasco, M. D. 2015. Highly diverse endophytic and soil Fusarium oxysporum populations associated with fieldgrown tomato plants. Appl. Environ. Microbiol. 81:81-90.

Dimkpa, C., Weinand, T., and Asch, F. 2009. Plant-rhizobacteria interactions alleviate abiotic stress conditions. Plant Cell Environ. 32: 1682-1694.

Dorosky, R. J., Pierson, L. S., and Pierson, E. A. 2018. Pseudomonas chlororaphis produces multiple R-tailocin particles that broaden the killing spectrum and contribute to persistence in rhizosphere communities. Appl. Environ. Microbiol. 84:e01230-18.

Douglas, A. E. 2015. Multiorganismal insects: Diversity and function of resident microorganisms. Annu. Rev. Entomol. 60:17-34.

Duhamel, M., and Vandenkoornhuyse, P. 2013. Sustainable agriculture: Possible trajectories from mutualistic symbiosis and plant neodomestication. Trends Plant Sci. 18:597-600.

Durak, R., Wegrzyn, E., and Leniowski, K. 2016. Do all aphids benefit from climate warming? An effect of temperature increase on a native species of temperate climatic zone Cinara juniperi. Ethol. Ecol. Evol. 28:188-201.

Erb, M., Glauser, G., and Robert, C. A. M. 2012. Induced immunity against belowground insect herbivores- activation of defenses in the absence of a jasmonate burst. J. Chem. Ecol. 38:629-640.

Eversole, K. 2016. Embracing complexity of crop phytobiomes with a multidisciplinary roadmap for phytobiomes research and an industryacademic research alliance. AGU Fall Meeting Abstracts.

Farrar, K., Bryant, D., and Cope-Selby, N. 2014. Understanding and engineering beneficial plant-microbe interactions: Plant growth promotion in energy crops. Plant Biotechnol. J. 12:1193-1206.

Fiegna, F., Moreno-Letelier, A., Bell, T., and Barraclough, T. G. 2015. Evolution of species interactions determines microbial community productivity in new environments. ISME J. 9:1235-1245.

Fitzpatrick, C. R., Copeland, J., Wang, P. W., Guttman, D. S., Kotanen, P. M., and Johnson, M. T. J. 2018. Assembly and ecological function of the root microbiome across angiosperm plant species. Proc. Natl. Acad. Sci. USA 115: E1157-E1165

Fontanazza, M. 2016. Consortium for sequencing the food supply chain archives. FoodSafetyTech. https://foodsafetytech.com/tag/consortium-forsequencing-the-food-supply-chain/

Freilich, M. A., Wieters, E., Broitman, B. R., Marquet, P. A., and Navarrete, S. A. 2018. Species co-occurrence networks: Can they reveal trophic and non-trophic interactions in ecological communities? Ecology 99:690-699.

Funck-Jensen, D., and Hockenhull, J. 1984. The influence of some factors on the severity of Pythium root rot of lettuce in soilless (hydroponic) growing systems. Acta Hortic. 133:129-136.
Gan, H. J., and Wickings, K. 2017. Soil ecological responses to pest management in golf turf vary with management intensity, pesticide identity, and application program. Agric. Ecosyst. Environ. 246:66-77.

Garner, D., and Kathariou, S. 2016. Fresh produce-associated Listeriosis outbreaks, sources of concern, teachable moments, and insights. J. Food Prot. 79:337-344.

Garrett, K. A. 2012. Information networks for disease: Commonalities in human management networks and within-host signalling networks. Eur. J. Plant Pathol. 133:75-88.

Garrett, K. A., Alcala-Briseno, R. I., Andersen, K. F., Buddenhagen, C. E., Choudhury, R. A., Fulton, J. C., Nopsa, J. F. H., Poudel, R., and Xing, Y. 2018. Network analysis: A systems framework to address grand challenges in plant pathology. Annu. Rev. Phytopathol. 56:559-580.

Garrett, K. A., Andersen, K. F., Asche, F., Bowden, R. L., Forbes, G. A., Kulakow, P. A., and Zhou, B. 2017. Resistance genes in global crop breeding networks. Phytopathology 107:1268-1278.

Ghequire, M. G. K., and De Mot, R. 2014. Ribosomally encoded antibacterial proteins and peptides from Pseudomonas. FEMS Microbiol. Rev. 38: 523-568.

Glenna, L., Shortall, S., and Brandl, B. 2015. Neoliberalism, the university, public goods and agricultural innovation. Sociol. Ruralis 55:438-459.

Golo, P. S., Gardner, D. R., Grilley, M. M., Takemoto, J. Y., Krasnoff, S. B., Pires, M. S., Fernandes, E. K. K., Bittencourt, V. R. E. P., and Roberts, D. W. 2014. Production of destruxins from Metarhizium spp. fungi in artificial medium and in endophytically colonized cowpea plants. PLoS One 9:e104946.

Great Lakes Phragmites Collaborative. 2018. https://www.greatlakesphragmites.net/

Guerreiro, M. A., Brachmann, A., Begerow, D., and Persoh, D. 2018. Transient leaf endophytes are the most active fungi in 1-year-old beech leaf litter. Fungal Divers. 89:237-251.

Gurulingappa, P., Sword, G. A., Murdoch, G., and Mcgee, P. A. 2010. Colonization of crop plants by fungal entomopathogens and their effects on two insect pests when in planta. Biol. Control 55:34-41.

Haas, D., and Defago, G. 2005. Biological control of soil-borne pathogens by fluorescent pseudomonads. Nat. Rev. Microbiol. 3:307-319.

Hamel, C., Gan, Y. T., Sokolski, S., and Bainard, L. D. 2018. High frequency cropping of pulses modifies soil nitrogen level and the rhizosphere bacterial microbiome in 4-year rotation systems of the semiarid prairie. Appl. Soil Ecol. 126:47-56.

Hawkes, C. V., and Connor, E. W. 2017. Translating phytobiomes from theory to practice: Ecological and evolutionary considerations. Phytobiomes 1: 57-69.

Hayes, C. S., Koskiniemi, S., Ruhe, Z. C., Poole, S. J., and Low, D. A. 2014. Mechanisms and biological roles of contact-dependent growth inhibition systems. Cold Spring Harb. Perspect. Med. 4:a010025.

Hazelton, E. L. G., Mozdzer, T. J., Burdick, D. M., Kettenring, K. M., and Whigham, D. F. 2014. Phragmites australis management in the United States: 40 years of methods and outcomes. AoB Plants 6:plu001.

Heisey, P. W., and Fuglie, K. O. 2018. Public agricultural R\&D in high-income countries: Old and new roles in a new funding environment. Glob. Food Secur. 17:92-102.

Hert, A. P., Marutani, M., Momol, M. T., Roberts, P. D., Olson, S. M., and Jones, J. B. 2009. Suppression of the bacterial spot pathogen Xanthomonas euvesicatoria on tomato leaves by an attenuated mutant of Xanthomonas perforans. Appl. Environ. Microbiol. 75:3323-3330.

Hogg, B. N., Bugg, R. L., and Daane, K. M. 2011. Attractiveness of common insectary and harvestable floral resources to beneficial insects. Biol. Control 56:76-84.

Howard, M. M., Bell, T. H., and Kao-Kniffin, J. 2017. Soil microbiome transfer method affects microbiome composition, including dominant microorganisms, in a novel environment. FEMS Microbiol. Lett. 364:fnx092.

Hu, G., and St. Leger, R.J. 2002. Field studies using a recombinant mycoinsecticide (Metarhizium anisopliae) reveal that it is rhizosphere competent. Appl. Environ. Microbiol. 68:6383-6387.

Hu, L. F., Robert, C. A. M., Cadot, S., Zhang, X., Ye, M., Li, B. B., Manzo, D., Chervet, N., Steinger, T., van der Heijden, M. G. A., Schlaeppi, K., and Erb, M. 2018. Root exudate metabolites drive plant-soil feedbacks on growth and defense by shaping the rhizosphere microbiota. Nat. Commun. 9:2738.

Isely, P., Nordman, E. E., Howard, S., and Bowman, R. 2017. Phragmites removal increases property values in Michigan's lower Grand River watershed. Journal Ocean and Coastal Economics 4:5.

Jaber, L. R., and Ownley, B. H. 2018. Can we use entomopathogenic fungi as endophytes for dual biological control of insect pests and plant pathogens? Biol. Control 116:36-45. 
Jarvis, K. G., White, J. R., Grim, C. J., Ewing, L., Ottesen, A. R., Beaubrun, J. J. G., Pettengill, J. B., Brown, E., and Hanes, D. E. 2015. Cilantro microbiome before and after nonselective pre-enrichment for Salmonella using 16S rRNA and metagenomic sequencing. BMC Microbiol. 15:160.

Jessop, B., Moulaert, F., Hulgard, L., and Hamdouch, A. 2013. Social innovation research: A new stage in innovation analysis? Pages 110-130 in: The International Handbook on Social Innovation: Collective Action, Social Learning and Transdisciplinary Research. B. Jessop, F. Moulaert, L. Hulgard, and A. Hamdouch, eds. Edward Elgar, Cheltenham, UK.

Johnson, L. J., de Bonth, A. C. M., Briggs, L. R., Caradus, J. R., Finch, S. C., Fleetwood, D. J., Fletcher, L. R., Hume, D. E., Johnson, R. D., Popay, A. J., Tapper, B. A., Simpson, W. R., Voisey, C. R., and Card, S. D. 2013a. The exploitation of epichloae endophytes for agricultural benefit. Fungal Divers. 60:171-188.

Johnson, N. C., Wilson, G. W. T., Bowker, M. A., Wilson, J. A., and Miller, R. M. 2010. Resource limitation is a driver of local adaptation in mycorrhizal symbioses. Proc. Natl. Acad. Sci. USA 107:2093-2098.

Johnson, S. N., Benefer, C. M., Frew, A., Griffiths, B. S., Hartley, S. E., Karley, A. J., Rasmann, S., Schumann, M., Sonnemann, I., and Robert, C. A. M. 2016. New frontiers in belowground ecology for plant protection from rootfeeding insects. Appl. Soil Ecol. 108:96-107.

Johnson, S. N., Mitchell, C., McNicol, J. W., Thompson, J., and Karley, A. J. 2013b. Downstairs drivers - root herbivores shape communities of aboveground herbivores and natural enemies via changes in plant nutrients. J. Anim. Ecol. 82:1021-1030.

Kaminsky, L., Thompson, G. L., Trexler, R., Bell, T. H., and Kao-Kniffin, J. 2018. Medicago sativa has reduced biomass and nodulation when grown with soil microbiomes conditioned to high phosphorus inputs. Phytobiomes J. 2: 237-248.

Kasim, W. A., Osman, M. E., Omar, M. N., Abd El-Daim, I. A., Bejai, S., and Meijer, J. 2013. Control of drought stress in wheat using plant-growthpromoting bacteria. J. Plant Growth Regul. 32:122-130.

Keith, A. R., Bailey, J. K., and Whitham, T. G. 2010. A genetic basis to community repeatability and stability. Ecology 91:3398-3406.

Keltner, D., and Haidt, J. 2003. Approaching awe, a moral, spiritual, and aesthetic emotion. Cogn. Emotion 17:297-314.

Kennedy, A. C. 2018. Selective soil bacteria to manage downy brome, jointed goatgrass, and medusahead and do no harm to other biota. Biol. Control 123: 18-27.

Kessler, A., and Baldwin, I. T. 2001. Defensive function of herbivore-induced plant volatile emissions in nature. Science 291:2141-2144.

Ketola, T., Mikonranta, L., and Mappes, J. 2016. Evolution of bacterial lifehistory traits is sensitive to community structure. Evolution 70:1334-1341.

Khan, Z. R., James, D. G., Midega, C. A. O., and Pickett, J. A. 2008. Chemical ecology and conservation biological control. Biol. Control 45:210-224.

Kido, K., Tanaka, C., Mochizuki, T., Kubota, K., Ohki, T., Ohnishi, J., Knight, L. M., and Tsuda, S. 2008. High temperatures activate local viral multiplication and cell-to-cell movement of Melon necrotic spot virus but restrict expression of systemic symptoms. Phytopathology 98:181-186.

King, A. M. Q., Adams, M. J., Carstens, E. B., and Lefkowicz, E. J. 2011. Virus Taxonomy: Ninth Report of the International Committee on Taxonomy of Viruses. Elsevier Academic Press, New York.

Kowalski, K. P., Bacon, C., Bickford, W., Braun, H., Clay, K., Leduc-Lapierre, M., Lillard, E., McCormick, M. K., Nelson, E., Torres, M., White, J., and Wilcox, D. A. 2015. Advancing the science of microbial symbiosis to support invasive species management: A case study on Phragmites in the Great Lakes. Front. Microbiol. 6:95.

Kuldau, G., and Bacon, C. 2008. Clavicipitaceous endophytes: Their ability to enhance resistance of grasses to multiple stresses. Biol. Control 46:57-71.

Kwak, Y. S., and Weller, D. M. 2013. Take-all of wheat and natural disease suppression: A review. Plant Pathol. J. 29:125-135.

Latef, A. A. H. A., Hashem, A., Rasool, S., Abd Allah, E. F., Alqarawi, A. A., Egamberdieva, D., Jan, S., Anjum, N. A., and Ahmad, P. 2016. Arbuscular mycorrhizal symbiosis and abiotic stress in plants: A review. J. Plant Biol. 59: 407-426.

Lau, J. A., and Lennon, J. T. 2012. Rapid responses of soil microorganisms improve plant fitness in novel environments. Proc. Natl. Acad. Sci. USA 109: 14058-14062.

Lauber, C. L., Hamady, M., Knight, R., and Fierer, N. 2009. Pyrosequencingbased assessment of soil $\mathrm{pH}$ as a predictor of soil bacterial community structure at the continental scale. Appl. Environ. Microbiol. 75:5111-5120.

Lawrence, D., Fiegna, F., Behrends, V., Bundy, J. G., Phillimore, A. B., Bell, T., and Barraclough, T. G. 2012. Species interactions alter evolutionary responses to a novel environment. PLoS Biol. 10:e1001330.
Lebeis, S. L. 2014. The potential for give and take in plant-microbiome relationships. Front. Plant Sci. 5:287.

Lebeis, S. L., Paredes, S. H., Lundberg, D. S., Breakfield, N., Gehring, J., McDonald, M., Malfatti, S., del Rio, T. G., Jones, C. D., Tringe, S. G., and Dangl, J. L. 2015. Salicylic acid modulates colonization of the root microbiome by specific bacterial taxa. Science 349:860-864.

Lebeis, S. L., Rott, M., Dangl, J. L., and Schulze-Lefert, P. 2012. Culturing a plant microbiome community at the cross-Rhodes. New Phytol. 196:341-344.

Leff, J. W., and Fierer, N. 2013. Bacterial communities associated with the surfaces of fresh fruits and vegetables. PLoS One 8:e59310.

Legg, J. P., Jeremiah, S. C., Obiero, H. M., Maruthi, M. N., Ndyetabula, I., Okao-Okuja, G., Bouwmeester, H., Bigirimana, S., Tata-Hangy, W., Gashaka, G., Mkamilo, G., Alicai, T., and Kumar, P. L. 2011. Comparing the regional epidemiology of the cassava mosaic and cassava brown streak virus pandemics in Africa. Virus Res. 159:161-170.

Legg, J. P., Kumar, P. L., Makeshkumar, T., Tripathi, L., Ferguson, M., Kanju, E., Ntawuruhunga, P., and Cuellar, W. 2015. Cassava virus diseases: Biology, epidemiology, and management. Adv. Virus Res. 91:85-142.

Lennon, J. T., and Jones, S. E. 2011. Microbial seed banks: The ecological and evolutionary implications of dormancy. Nat. Rev. Microbiol. 9:119-130.

Lesk, C., Rowhani, P., and Ramankutty, N. 2016. Influence of extreme weather disasters on global crop production. Nature 529:84-87.

Letourneau, D. K., Armbrecht, I., Rivera, B. S., Lerma, J. M., Carmona, E. J., Daza, M. C., Escobar, S., Galindo, V., Gutierrez, C., Lopez, S. D., Mejia, J. L., Rangel, A. M. A., Rangel, J. H., Rivera, L., Saavedra, C. A., Torres, A. M., and Trujillo, A. R. 2011. Does plant diversity benefit agroecosystems? A synthetic review. Ecol. Appl. 21:9-21.

Leveau, J. H. J. 2007. The magic and menace of metagenomics: Prospects for the study of plant growth-promoting rhizobacteria. Eur. J. Plant Pathol. 119: 279-300.

Li, P. F., Zhou, H. W., Di, G. H., Liu, J., Liu, Y., Wang, Z. H., Sun, Y. X., Duan, H. F., and Sun, J. Z. 2017. Mesenchymal stem cell-conditioned medium promotes MDA-MB-231 cell migration and inhibits A549 cell migration by regulating insulin receptor and human epidermal growth factor receptor 3 phosphorylation. Oncol. Lett. 13:1581-1586.

Lilleskov, E. A., and Bruns, T. D. 2005. Spore dispersal of a resupinate ectomycorrhizal fungus, Tomentella sublilacina, via soil food webs. Mycologia 97:762-769.

Lopez, D. C., and Sword, G. A. 2015. The endophytic fungal entomopathogens Beauveria bassiana and Purpureocillium lilacinum enhance the growth of cultivated cotton (Gossypium hirsutum) and negatively affect survival of the cotton bollworm (Helicoverpa zea). Biol. Control 89:53-60.

Lopez, D. C., Zhu-Salzman, K., Ek-Ramos, M. J., and Sword, G. A. 2014. The entomopathogenic fungal endophytes Purpureocillium lilacinum (formerly Paecilomyces lilacinus) and Beauveria bassiana negatively affect cotton aphid reproduction under both greenhouse and field conditions. PLoS One 9:e103891.

Lopez, R., and Galinato, G. I. 2007. Should governments stop subsidies to private goods? Evidence from rural Latin America. J. Public Econ. 91: 1071-1094.

Ma, X. M., Liu, Y., Zarebanadkouki, M., Razavi, B. S., Blagodatskaya, E., and Kuzyakov, Y. 2018. Spatiotemporal patterns of enzyme activities in the rhizosphere: effects of plant growth and root morphology. Biol. Fertil. Soils 54:819-828.

Malcolm, G. M., Kuldau, G. A., Gugino, B. K., and Jimenez-Gasco, M. D. 2013. Hidden host plant associations of soilborne fungal pathogens: An ecological perspective. Phytopathology 103:538-544.

Mantzoukas, S., Chondrogiannis, C., and Grammatikopoulos, G. 2015. Effects of three endophytic entomopathogens on sweet sorghum and on the larvae of the stalk borer Sesamia nonagrioides. Entomol. Exp. Appl. 154:78-87.

Martin, L. J., and Blossey, B. 2013. The runaway weed: Costs and failures of Phragmites australis management in the USA. Estuaries Coasts 36:626-632.

Martinuz, A., Schouten, A., and Sikora, R. A. 2012. Systemically induced resistance and microbial competitive exclusion: Implications on biological control. Phytopathology 102:260-266.

Martiny, J. B. H., Martiny, A. C., Weihe, C., Lu, Y., Berlemont, R., Brodie, E. L., Goulden, M. L., Treseder, K. K., and Allison, S. D. 2017. Microbial legacies alter decomposition in response to simulated global change. ISME J. 11:490-499.

Mase, A. S., Gramig, B. M., and Prokopy, L. S. 2017. Climate change beliefs, risk perceptions, and adaptation behavior among Midwestern U.S. crop farmers. Clim. Risk Manage. 15:8-17.

Massart, S., Olmos, A., Jijakli, H., and Candresse, T. 2014. Current impact and future directions of high throughput sequencing in plant virus diagnostics. Virus Res. 188:90-96. 
McDaniel, M. D., Tiemann, L. K., and Grandy, A. S. 2014. Does agricultural crop diversity enhance soil microbial biomass and organic matter dynamics? A meta-analysis. Ecol. Appl. 24:560-570.

Mithofer, A., and Boland, W. 2012. Plant defense against herbivores: Chemical aspects. Annu. Rev. Plant Biol. 63:431-450.

Moulaert, F., MacCallum, D., Mehmood, A., and Hamdouch, A. 2013. General introduction: the return of social innovation as a scientific concept and a social practice. Pages 1-6 in: International Handbook on Social Innovation: Collective Action, Social Learning and Transdisciplinary Research. F. Moulaert, D. MacCallum, A. Mehmood, and A. Hamdouch, eds. Edward Elgar, Cheltenham, U.K.

Mueller, U. G., and Sachs, J. L. 2015. Engineering microbiomes to improve plant and animal health. Trends Microbiol. 23:606-617.

Mutune, B., Ekesi, S., Niassy, S., Matiru, V., Bii, C., and Maniania, N. K. 2016. Fungal endophytes as promising tools for the management of bean stem maggot Ophiomyia phaseoli on beans Phaseolus vulgaris. J. Pest Sci. 89: 993-1001.

Muvea, A. M., Meyhofer, R., Subramanian, S., Poehling, H. M., Ekesi, S., and Maniania, N. K. 2014. Colonization of onions by endophytic fungi and their impacts on the biology of Thrips tabaci. PLoS One 9:e108242.

Nabi, R. L., and Myrick, J. G. 2018. Uplifting fear appeals: Considering the role of hope in fear-based persuasive messages. Health Commun. 9:1-12.

Naranjo, S. E., and Ellsworth, P. C. 2009. Fifty years of the integrated control concept: Moving the model and implementation forward in Arizona. Pest Manag. Sci. 65:1267-1286.

National Academies of Sciences Engineering and Medicine. 2017. Communicating science effectively: A research agenda. National Academies Press, Washington, DC.

Newsham, K. K. 2011. A meta-analysis of plant responses to dark septate root endophytes. New Phytol. 190:783-793.

Ngumbi, E., and Kloepper, J. 2016. Bacterial-mediated drought tolerance: Current and future prospects. Appl. Soil Ecol. 105:109-125.

Nogales, A., Nobre, T., Valadas, V., Ragonezi, C., Doring, M., Polidoros, A., and Arnholdt-Schmitt, B. 2016. Can functional hologenomics aid tackling current challenges in plant breeding? Brief. Funct. Genomics 15:288-297.

Ottesen, A. R., Gorham, S., Reed, E., Newell, M. J., Ramachandra, P., Canida, T., Allard, M., Evans, P., Brown, E., and White, J. R. 2016. Using a control to better understand phyllosphere microbiota. PLoS One 11:e0163482.

Pangesti, N., Pineda, A., Pieterse, C. M. J., Dicke, M., and van Loon, J. J. A. 2013. Two-way plant-mediated interactions between root-associated microbes and insects: From ecology to mechanisms. Front. Plant Sci. 4:414.

Parnell, J. J., Berka, R., Young, H. A., Sturino, J. M., Kang, Y. W., Barnhart, D. M., and DiLeo, M. V. 2016. From the lab to the farm: An industrial perspective of plant beneficial microorganisms. Front. Plant Sci. 7:1110

Pava-Ripoll, M., Angelini, C., Fang, W. G., Wang, S. B., Posada, F. J., and St, Leger, R. 2011. The rhizosphere-competent entomopathogen Metarhizium anisopliae expresses a specific subset of genes in plant root exudate. Microbiol. SGM 157:47-55.

Peterson, J. A., Ode, P. J., Oliveira-Hofman, C., and Harwood, J. D. 2016. Integration of plant defense traits with biological control of arthropod pests: Challenges and opportunities. Front. Plant Sci. 7:1794

Petrini, O. 1991. Fungal endophytes of tree leaves. Pages 179-197 in: Microbial Ecology of Leaves. J. H. Andrews and S. S. Hirano, eds. Springer-Verlag, New York.

Pieterse, C. M. J., Zamioudis, C., Berendsen, R. L., Weller, D. M., Van Wees, S. C. M., and Bakker, P. A. H. M. 2014. Induced systemic resistance by beneficial microbes. Annu. Rev. Phytopathol. 52:347-375.

Pineda, A., Kaplan, I., and Bezemer, T. M. 2017. Steering soil microbiomes to suppress aboveground insect pests. Trends Plant Sci. 22:770-778.

Pineda, A., Soler, R., Weldegergis, B. T., Shimwela, M. M., Van Loon, J. J. A., and Dicke, M. 2013. Non-pathogenic rhizobacteria interfere with the attraction of parasitoids to aphid-induced plant volatiles via jasmonic acid signalling. Plant Cell Environ. 36:393-404.

Poelman, E. H. 2015. From induced resistance to defence in plant-insect interactions. Entomol. Exp. Appl. 157:11-17.

Poudel, R., Jumpponen, A., Schlatter, D., Paulitz, T., Gardener, B. M., Kinkel, L., and Garrett, K. 2016. Microbiome networks: A systems framework for identifying candidate microbial assemblages for disease management. Phytopathology 106:1083-1096.

Poveda, K., Jimenez, M. I. G., and Kessler, A. 2010. The enemy as ally: Herbivore-induced increase in crop yield. Ecol. Appl. 20:1787-1793.

Quesada-Moraga, E., Herrero, N., and Zabalgogeazcoa, I. 2014.

Entomopathogenic and nematophagous fungal endophytes. Pages 85-99 in: Advances in Endophytic Research. V. C. Verma and A. C. Gange, eds. Springer-Verlag, Heidelberg, Germany.
Rasmann, S., Kollner, T. G., Degenhardt, J., Hiltpold, I., Toepfer, S., Kuhlmann, U., Gershenzon, J., and Turlings, T. C. J. 2005. Recruitment of entomopathogenic nematodes by insect-damaged maize roots. Nature 434:732-737.

Rastogi, G., Coaker, G. L., and Leveau, J. H. J. 2013. New insights into the structure and function of phyllosphere microbiota through high-throughput molecular approaches. FEMS Microbiol. Lett. 348:1-10.

Reinhart, K. O., and Callaway, R. M. 2006. Soil biota and invasive plants. New Phytol. 170:445-457.

Revillini, D., Gehring, C. A., and Johnson, N. C. 2016. The role of locally adapted mycorrhizas and rhizobacteria in plant-soil feedback systems. Funct. Ecol. 30:1086-1098.

Rho, H., Hsieh, M., Kandel, S. L., Cantillo, J., Doty, S. L., and Kim, S. H. 2018. Do endophytes promote growth of host plants under stress? A meta-analysis on plant stress mitigation by endophytes. Microbiol. Ecol. 75:407-418.

Rillig, M. C., Antonovics, J., Caruso, T., Lehmann, A., Powell, J. R., Veresoglou, S. D., and Verbruggen, E. 2015. Interchange of entire communities: Microbial community coalescence. Trends Ecol. Evol. 30:470-476.

Rios-Moreno, A., Garrido-Jurado, I., Resquin-Romero, G., Arroyo-Manzanares, N., Arce, L., and Quesada-Moraga, E. 2016. Destruxin A production by Metarhizium brunneum strains during transient endophytic colonisation of Solanum tuberosum. Biocontrol Sci. Technol. 26:1574-1585.

Rivett, D. W., Jones, M. L., Ramoneda, J., Mombrikotb, S. B., Ransome, E., and Bell, T. 2018. Elevated success of multispecies bacterial invasions impacts community composition during ecological succession. Ecol. Lett. 21: 516-524.

Robert-Seilaniantz, A., MacLean, D., Jikumaru, Y., Hill, L., Yamaguchi, S., Kamiya, Y., and Jones, J. D. G. 2011. The microRNA miR393 re-directs secondary metabolite biosynthesis away from camalexin and towards glucosinolates. Plant J. 67:218-231.

Rodrigues, R. A. L., Andrade, A. C. D. P., Boratto, P. V. D., Trindade, G. D., Kroon, E. G., and Abrahao, J. S. 2017. An anthropocentric view of the virosphere-host relationship. Front. Microbiol. 8:1673.

Rodriguez, R. J., Henson, J., Van Volkenburgh, E., Hoy, M., Wright, L., Beckwith, F., Kim, Y. O., and Redman, R. S. 2008. Stress tolerance in plants via habitat-adapted symbiosis. ISME J. 2:404-416.

Rodriguez, R. J., White, J. F., Arnold, A. E., and Redman, R. S. 2009. Fungal endophytes: Diversity and functional roles. New Phytol. 182:314-330.

Rolli, E., Marasco, R., Vigani, G., Ettoumi, B., Mapelli, F., Deangelis, M. L., Gandolfi, C., Casati, E., Previtali, F., Gerbino, R., Cei, F. P., Borin, S., Sorlini, C., Zocchi, G., and Daffonchio, D. 2015. Improved plant resistance to drought is promoted by the root-associated microbiome as a water stress-dependent trait. Environ. Microbiol. 17:316-331.

Roos, J., Hopkins, R., Kvarnheden, A., and Dixelius, C. 2011. The impact of global warming on plant diseases and insect vectors in Sweden. Eur. J. Plant Pathol. 129:9-19.

Roossinck, M. J. 2015. Plants, viruses and the environment: Ecology and mutualism. Virology 479-480:271-277.

Roossinck, M. J., Sabanadzovic, S., Okada, R., and Valverde, R. A. 2011. The remarkable evolutionary history of endornaviruses. J. Gen. Virol. 92: 2674-2678.

Rosenberg, E., and Zilber-Rosenberg, I. 2016. Microbes drive evolution of animals and plants: The hologenome concept. MBio 7:e01395-e01315.

Rosenheim, J. A., Parsa, S., Forbes, A. A., Krimmel, W. A., Law, Y. H., Segoli, M., Segoli, M., Sivakoff, F. S., Zaviezo, T., and Gross, K. 2011. Ecoinformatics for integrated pest management: expanding the applied insect ecologist's tool-kit. J. Econ. Entomol. 104:331-342.

Rossouw, W., and Korsten, L. 2017. Cultivable microbiome of fresh white button mushrooms. Lett. Appl. Microbiol. 64:164-170.

Sasan, R. K., and Bidochka, M. J. 2012. The insect-pathogenic fungus Metarhizium robertsii (Clavicipitaceae) is also an endophyte that stimulates plant root development. Am. J. Bot. 99:101-107.

Sasse, J., Martinoia, E., and Northen, T. 2018. Feed your friends: Do plant exudates shape the root microbiome? Trends Plant Sci. 23:25-41.

Schardl, C. L., Leuchtmann, A., and Spiering, M. J. 2004. Symbioses of grasses with seedborne fungal endophytes. Annu. Rev. Plant Biol. 55:315-340.

Schlatter, D., Kinkel, L., Thomashow, L., Weller, D., and Paulitz, T. 2017. Disease suppressive soils: New insights from the soil microbiome. Phytopathology 107:1284-1297.

Schmid, J., Day, R., Zhang, N. X., Dupont, P. Y., Cox, M. P., Schardl, C. L., Minards, N., Truglio, M., Moore, N., Harris, D. R., and Zhou, Y. F. 2017. Host tissue environment directs activities of an Epichlö̈ endophyte, while it induces systemic hormone and defense responses in its native perennial ryegrass host. Mol. Plant Microbe Interact. 30:138-149. 
Seastedt, T. R. 1984. The role of microarthropods in decomposition and mineralization processes. Annu. Rev. Entomol. 29:25-46.

Shade, A., and Gilbert, J. A. 2015. Temporal patterns of rarity provide a more complete view of microbial diversity. Trends Microbiol. 23:335-340.

Shearer, E. 2018. Americans interested in the environment are the most likely to feel civic obligation to follow science news. Pew Research Center, Washington, DC.

Shearin, Z. R. C., Filipek, M., Desai, R., Bickford, W. A., Kowalski, K. P., and Clay, K. 2018. Fungal endophytes from seeds of invasive, non-native Phragmites australis and their potential role in germination and seedling growth. Plant Soil 422:183-194.

Shi, S. J., Nuccio, E. E., Shi, Z. J., He, Z. L., Zhou, J. Z., and Firestone, M. K. 2016. The interconnected rhizosphere: High network complexity dominates rhizosphere assemblages. Ecol. Lett. 19:926-936.

Shuster, W. D., Subler, S., and McCoy, E. L. 2001. Deep-burrowing earthworm additions changed the distribution of soil organic carbon in a chisel-tilled soil. Soil Biol. Biochem. 33:983-996.

Sikora, R. A., Pocasangre, L., zum Felde, A., Niere, B., Vu, T. T., and Dababat, A. A. 2008. Mutualistic endophytic fungi and in-planta suppressiveness to plant parasitic nematodes. Biol. Control 46:15-23.

Singh, B. K., Trivedi, P., Singh, S., Macdonald, C. A., and Verma, J. P. 2018. Emerging microbiome technologies for sustainable increase in farm productivity and environmental security. Microbiol. Aust. 39:17-23.

Six, J., Bossuyt, H., Degryze, S., and Denef, K. 2004. A history of research on the link between (micro)aggregates, soil biota, and soil organic matter dynamics. Soil Tillage Res. 79:7-31.

Soares, M. A., Li, H. Y., Kowalski, K. P., Bergen, M., Torres, M. S., and White, J. F. 2016. Functional role of bacteria from invasive Phragmites australis in promotion of host growth. Microb. Ecol. 72:407-417.

Squillace, P. J., Scott, J. C., Moran, M. J., Nolan, B. T., and Kolpin, D. W. 2002. VOCs, pesticides, nitrate, and their mixtures in groundwater used for drinking water in the United States. Environ. Sci. Technol. 36:1923-1930.

St. Leger, R. J. 2008. Studies on adaptations of Metarhizium anisopliae to life in the soil. J. Invertebr. Pathol. 98:271-276.

Stam, J. M., Kroes, A., Li, Y. H., Gols, R., van Loon, J. J. A., Poelman, E. H., and Dicke, M. 2014. Plant interactions with multiple insect herbivores: From community to genes. Annu. Rev. Plant Biol. 65:689-713.

Stergiopoulos, I., and Gordon, T. R. 2014. Cryptic fungal infections: The hidden agenda of plant pathogens. Front. Plant Sci. 5:506.

Stewart, J. E., Kim, M. S., and Klopfenstein, N. B. 2018. Molecular genetic approaches toward understanding forest-associated fungi and their interactive roles within forest ecosystems. Curr. For. Rep. 4:72-84.

Stuber, C. W. 1994. Breeding multigenic traits. Pages 97-115 in: DNA-Based Markers in Plants. R. L. Phillips and I. K. Vasil, eds. Springer, Dordrecht. Suttle, C. A. 2005. Viruses in the sea. Nature 437:356-361.

Tamiru, A., Bruce, T. J. A., Midega, C. A. O., Woodcock, C. M., Birkett, M. A., Pickett, J. A., and Khan, Z. R. 2012. Oviposition induced volatile emissions from African smallholder farmers' maize varieties. J. Chem. Ecol. 38:231-234.

Tanaka, A., Takemoto, D., Chujo, T., and Scott, B. 2012. Fungal endophytes of grasses. Curr. Opin. Plant Biol. 15:462-468.

Tedersoo, L., Bahram, M., Polme, S., Koljalg, U., Yorou, N. S., Wijesundera, R., Ruiz, L. V., Vasco-Palacios, A. M., Thu, P. Q., Suija, A., Smith, M. E., Sharp, C., Saluveer, E., Saitta, A., Rosas, M., Riit, T., Ratkowsky, D., Pritsch, K., Poldmaa, K., Piepenbring, M., Phosri, C., Peterson, M., Parts, K., Partel, K., Otsing, E., Nouhra, E., Njouonkou, A. L., Nilsson, R. H., Morgado, L. N., Mayor, J., May, T. W., Majuakim, L., Lodge, D. J., Lee, S. S., Larsson, K. H., Kohout, P., Hosaka, K., Hiiesalu, I., Henkel, T. W., Harend, H., Guo, L. D., Greslebin, A., Grelet, G., Geml, J., Gates, G., Dunstan, W., Dunk, C., Drenkhan, R., Dearnaley, J., De Kesel, A., Dang, T., Chen, X., Buegger, F., Brearley, F. Q., Bonito, G., Anslan, S., Abell, S., and Abarenkov, K. 2014. Global diversity and geography of soil fungi. Science 346:1256688.

Thomas-Sharma, S., Andrade-Piedra, J., Yepes, M. C., Nopsa, J. F. H., Jeger, M. J., Jones, R. A. C., Kromann, P., Legg, J. P., Yuen, J., Forbes, G. A., and Garrett, K. A. 2017. A risk assessment framework for seed degeneration: Informing an integrated seed health strategy for vegetatively propagated crops. Phytopathology 107:1123-1135.

Treseder, K. K. 2008. Nitrogen additions and microbial biomass: A metaanalysis of ecosystem studies. Ecol. Lett. 11:1111-1120.

Treseder, K. K., Kivlin, S. N., and Hawkes, C. V. 2011. Evolutionary trade-offs among decomposers determine responses to nitrogen enrichment. Ecol. Lett. 14:933-938

Tscharntke, T., Sekercioglu, C. H., Dietsch, T. V., Sodhi, N. S., Hoehn, P., and Tylianakis, J. M. 2008. Landscape constraints on functional diversity of birds and insects in tropical agroecosystems. Ecology 89:944-951.
Turlings, T. C. J., Tumlinson, J. H., and Lewis, W. J. 1990. Exploitation of herbivore-induced plant odors by host-seeking parasitic wasps. Science 250: 1251-1253.

Ungerer, M. C., Johnson, L. C., and Herman, M. A. 2008. Ecological genomics: Understanding gene and genome function in the natural environment. Heredity 100:178-183.

van der Meijden, E., and Klinkhamer, P. G. L. 2000. Conflicting interests of plants and the natural enemies of herbivores. Oikos 89:202-208.

Vance, V. B. 1991. Replication of potato virus X RNA is altered in coinfections with potato virus Y. Virology 182:486-494.

Vannette, R. L., and Fukami, T. 2014. Historical contingency in species interactions: towards niche-based predictions. Ecol. Lett. 17:115-124.

Walker, M., and Jones, T. H. 2001. Relative roles of top-down and bottom-up forces in terrestrial tritrophic plant-insect herbivore-natural enemy systems. Oikos 93:177-187

Wani, Z. A., Ashraf, N., Mohiuddin, T., and Riyaz-Ul-Hassan, S. 2015. Plantendophyte symbiosis, an ecological perspective. Appl. Microbiol. Biotechnol. 99:2955-2965.

Weinstein, M. P., and Balletto, J. H. 1999. Does the common reed, Phragmites australis, affect essential fish habitat? Estuaries 22:793-802.

White, J. F., Kingsley, K. I., Kowalski, K. P., Irizarry, I., Micci, A., Soares, M. A., and Bergen, M. S. 2018. Disease protection and allelopathic interactions of seed-transmitted endophytic pseudomonads of invasive reed grass (Phragmites australis). Plant Soil 422:195-208.

Wickings, K., and Grandy, A. S. 2011. The oribatid mite Scheloribates moestus (Acari: Oribatida) alters litter chemistry and nutrient cycling during decomposition. Soil Biol. Biochem. 43:351-358.

Wickings, K., and Grandy, A. S. 2013. Management intensity interacts with litter chemistry and climate to drive temporal patterns in arthropod communities during decomposition. Pedobiologia (Jena) 56:105-112.

Williams, T. R., and Marco, M. L. 2014. Phyllosphere microbiota composition and microbial community transplantation on lettuce plants grown indoors. MBio 5:e01564-e01514

Wilson, D. 1995. Endophyte-The evolution of a term, and clarification of its use and definition. Oikos 73:274-276.

Wolf, A. B., Vos, M., de Boer, W., and Kowalchuk, G. A. 2013. Impact of matric potential and pore size distribution on growth dynamics of filamentous and non-filamentous soil bacteria. PLoS One 8:e83661.

Xu, L., Naylor, D., Dong, Z. B., Simmons, T., Pierroz, G., Hixson, K. K., Kim, Y. M., Zink, E. M., Engbrecht, K. M., Wang, Y., Gao, C., DeGraaf, S., Madera, M. A., Sievert, J. A., Hollingsworth, J., Birdseye, D., Scheller, H. V., Hutmacher, R., Dahlberg, J., Jansson, C., Taylor, J. W., Lemaux, P. G., and Coleman-Derr, D. 2018. Drought delays development of the sorghum root microbiome and enriches for monoderm bacteria. Proc. Natl. Acad. Sci. USA 115:E4284-E4293.

Xu, X. M., Jeffries, P., Pautasso, M., and Jeger, M. J. 2011. Combined use of biocontrol agents to manage plant diseases in theory and practice. Phytopathology 101:1024-1031.

Xuan, W., Beeckman, T., and Xu, G. H. 2017. Plant nitrogen nutrition: Sensing and signaling. Curr. Opin. Plant Biol. 39:57-65.

Yergeau, E., Bell, T. H., Champagne, J., Maynard, C., Tardif, S., Tremblay, J., and Greer, C. W. 2015. Transplanting soil microbiomes leads to lasting effects on willow growth, but not on the rhizosphere microbiome. Front. Microbiol. 6 .

Zhalnina, K., Louie, K. B., Hao, Z., Mansoori, N., da Rocha, U. N., Shi, S. J., Cho, H. J., Karaoz, U., Loque, D., Bowen, B. P., Firestone, M. K., Northen, T. R., and Brodie, E. L. 2018. Dynamic root exudate chemistry and microbial substrate preferences drive patterns in rhizosphere microbial community assembly. Nat. Microbiol. 3:470-480.

Zhang, L., Xu, M. G., Liu, Y., Zhang, F. S., Hodge, A., and Feng, G. 2016. Carbon and phosphorus exchange may enable cooperation between an arbuscular mycorrhizal fungus and a phosphate-solubilizing bacterium. New Phytol. 210:1022-1032.

Zhao, T., Podtburg, T. C., Zhao, P., Chen, D., Baker, D. A., Cords, B., and Doyle, M. P. 2013. Reduction by competitive bacteria of Listeria monocytogenes in biofilms and Listeria bacteria in floor drains in a ready-toeat poultry processing plant. J. Food Prot. 76:601-607.

Zhu, B., Gutknecht, J. L. M., Herman, D. J., Keck, D. C., Firestone, M. K., and Cheng, W. X. 2014a. Rhizosphere priming effects on soil carbon and nitrogen mineralization. Soil Biol. Biochem. 76:183-192.

Zhu, F., Poelman, E. H., and Dicke, M. 2014b. Insect herbivore-associated organisms affect plant responses to herbivory. New Phytol. 204:315-321.

Zilber-Rosenberg, I., and Rosenberg, E. 2008. Role of microorganisms in the evolution of animals and plants: The hologenome theory of evolution. FEMS Microbiol. Rev. 32:723-735. 